SJ Quinney College of Law, University of Utah Utah Law Digital Commons

Utah Law Faculty Scholarship

Utah Law Scholarship

2011

\title{
Controlling Greenhouse Gases from Highway Vehicles
}

Arnold W. Reitze Jr.

S.J. Quinney College of Law, University of Utah

Follow this and additional works at: https://dc.law.utah.edu/scholarship

Part of the Environmental Law Commons

\section{Recommended Citation}

Reitze, Arnold W., Controlling Greenhouse Gases from Highway Vehicles, 31 Utah Envtl. L. Rev. 309 (2011)

This Article is brought to you for free and open access by the Utah Law Scholarship at Utah Law Digital Commons. It has been accepted for inclusion in Utah Law Faculty Scholarship by an authorized administrator of Utah Law Digital Commons. For more information, please contact valeri.craigle@law.utah.edu. 
31 Utah Envtl. L. Rev. 309

\section{Utah Environmental Law Review \\ 2011}

Symposium: The Future of Energy Law

CONTROLLING GREENHOUSE GASES FROM HIGHWAY VEHICLES

Arnold W. Reitze, Jr. ${ }^{\mathrm{a}}$

Copyright (c) 2011 Utah Environmental Law Review; Arnold W. Reitze, Jr.

\section{Introduction}

For the past twenty years there has been a concern in the scientific community that anthropogenic emissions of greenhouse gases (GHGs), including carbon dioxide $\left(\mathrm{CO}_{2}\right)$ are affecting the planet's climate. GHGs are a fraction of 1 percent of the air and $\mathrm{CO}_{2}$ is 0.0360 percent of the gases that comprise the atmosphere. But GHGs play an important role in regulating the earth's temperature. ${ }^{1}$ Pre-industrial $\mathrm{CO}_{2}$ levels were about 280 parts per billion (ppb) but rose to about 385 ppb in 2007 and continue to increase by about 2 ppb per year. ${ }^{2}$ The United States emits about 21 percent of the world's GHGs, ${ }^{3}$ and approximately 85.1 percent of the GHGs emitted by human activity in the U.S. is $\mathrm{CO}_{2}{ }^{4}$ For that reason $\mathrm{CO}_{2}$ is the focus of most government actions designed to reduce GHG emissions.

In 2008, fossil fuel combustion sources accounted for 94.16 percent of the U.S. $\mathrm{CO}_{2}$ emissions. ${ }^{5}$ Transportation was responsible for 33.2 percent of the U.S. $\mathrm{CO}_{2}$ emissions from fossil fuel combustion in 2008, which makes it the end-use sector releasing the most $\mathrm{CO}_{2} \cdot{ }^{6}$ Moreover, from 1990 to 2008, U.S. $\mathrm{CO}_{2}$ emissions *310 increased by 16.08 percent, but

during those years $\mathrm{CO}_{2}$ emissions from transportation sources increased 20.15 percent. ${ }^{7}$ Petroleum combustion was responsible for 97.9 percent of the transportation sector's $\mathrm{CO}_{2}$ emissions and 59.9 percent of the emissions were from the gasoline used by motor vehicles. ${ }^{8}$

Long before there was any concern over climate change and the role of GHGs, mobile sources were regulated because they are important sources of conventional air pollutants. In 2008, mobile sources were responsible for the release of 73.2 percent of the nation's carbon monoxide (CO), 57.9 percent of the nitrogen oxides $\left(\mathrm{NO}_{\mathrm{x}}\right), 37.7$ percent of the volatile organic compounds (VOCs), small amounts of sulfur dioxide $\left(\mathrm{SO}_{2}\right)$, and particulate matter (PM). ${ }^{9}$ These conventional air pollutants are capable of being minimized through control of the combustion process, using clean fuel, and by using air pollution control devices. ${ }^{10}$ They have been subject to an extensive federal regulatory program administered by the Environmental Protection Agency (EPA) for four decades. ${ }^{11}$

However, $\mathrm{CO}_{2}$ differs from conventional pollutants in some important ways. When hydrocarbons in fuel react with air under chemically ideal combustion conditions, they produce $\mathrm{CO}_{2}$, water vapor and heat. ${ }^{12}$ The hot gases of combustion are converted to mechanical energy by the engine, and power is delivered to the wheels of a motor vehicle. If the combustion process is not chemically perfect, conventional pollutants are also produced. ${ }^{13}$ But, $\mathrm{CO}_{2}$ is the inherent byproduct of the thermodynamic process that powers the world's economy, even if the combustion process is chemically perfect. ${ }^{14}$ Unlike conventional pollutants, at this time there is no known cost effective technology to capture $\mathrm{CO}_{2}$ from mobile sources and no technology is expected to be developed in the foreseeable future. ${ }^{15}$ Therefore, if $\mathrm{CO}_{2}$ is to be controlled from mobile sources, 
people must drive less, use more fuel-efficient vehicles, or do both. Reducing $\mathrm{CO}_{2}$ emissions is both an engineering problem and a political/social problem, and the latter is the more difficult problem to overcome.

*311 Americans have had a love affair with motor vehicles for more than a century. ${ }^{16}$ But in recent years the U.S. motor vehicle industry has not prospered. Employment in the manufacture of automobiles and light-duty trucks in 2009 was about half what it was in 1999, and employment in manufacturing heavy-duty trucks was down even more. ${ }^{17}$ The federal government supports both the motor vehicle industry and the American driver by providing massive infrastructure investment in a highway system. ${ }^{18}$ The fiscal year 2010 budget for the U.S. Department of Transportation is over $\$ 73$ billion of which nearly $\$ 42$ billion is for the Federal Highway Administration. ${ }^{19}$ In recent years, a larger percentage of the transportation budget has been going to non-highway transportation, particularly mass transit ( $\$ 10.366$ billion) and railroads $(\$ 2.705$ billion), but the funding of highway construction continues to dominate the transportation budget. ${ }^{20}$

Although changing the transportation system to have less dependency on motor vehicles is needed if air pollution and GHG emissions are to be reduced, such efforts are strongly resisted by conservative political interests. ${ }^{21}$ In addition to infrastructure support, the federal government has provided billions of dollars to bailout some members of the automotive industry that were on the brink of ruin. ${ }^{22}$ Like the financial services industry, the automotive industry appears to be too big to fail. Thus, the federal government is a major financial supporter of the motor vehicle industry, because it is a vital part of the nation's economy. But the federal government also regulates the industry. This means that additional regulation of motor vehicles must deal with the interplay between jobs and environmental protection.

The consumption of transportation is usually expressed in terms of vehicle miles traveled (VMT). Getting the public to lower VMT is difficult. In the long run, this will require changes in land use and lifestyles that may not be politically possible, absent some major crisis. VMT increases are heavily driven by population increases. Total vehicle miles increased from $2,144,362$ miles in 1990 to 2,973,509 miles in 2008, which is a 38.67 percent increase. ${ }^{23}$ The population increase of 54.35 million from 1990 to 2008 appears to be responsible for about 55 percent of the increase in VMT. ${ }^{24}$ However, the U.S. VMT per capita also $* \mathbf{3 1 2}$ increased from 8,573 miles in 1990 to 10,051 miles in 2007, which is a 17.24 percent increase. ${ }^{25}$ The per capita increase shows that social and economic influences are also contributing to VMT increases. The combination of population increases and consumer choice has contributed to the nearly tripling of VMT since $1970{ }^{26}$ With the VMT averaging an increase of 1.2 percent a year from 1998 to 2008, it is very difficult to improve efficiency enough to overcome the increasing $\mathrm{CO}_{2}$ emissions caused by VMT increases. ${ }^{27}$

Reducing VMT could possibly be achieved by making driving significantly more expensive through the use of higher gasoline taxes, cap-and-trade programs or other economic approaches. ${ }^{28}$ However, the national elections in November 2010 demonstrate how difficult it will be to increase taxes. The increase in gasoline cost at the pump over the past decades has had little effect on VMT, but gasoline prices only increased by 20.7 percent from 1958 to 2010 when adjusted for inflation. ${ }^{29}$ Several studies of major metropolitan areas around the globe have found that increasing the costs of auto travel, such as by gasoline taxes, will reduce VMT, but the ratios of cost increases to decreased VMT is large. ${ }^{30}$

The other approach is to increase fuel efficiency from motor vehicles. A National Academy of Sciences study in 2001 concluded that it is possible to obtain a 40 percent increase in fuel efficiency in light-duty trucks and sport utility vehicles (SUVs) at costs that could be recovered over the lifetime of ownership. ${ }^{31}$ However, if car buyers selected vehicles with enhanced performance (requiring more fuel), or if the improvement in fuel economy led to an increase in VMT then improvements in efficiency may be nullified. ${ }^{32}$ Another study found the potential for motor vehicle fuel efficiency improvements by 2015 is only 10 to 15 percent; a mid-range 12.5 percent improvement would result in about an 11 percent $\mathrm{CO}_{2}$ emission reduction. ${ }^{33}$ Ultimately, using existing technology, GHG emissions could be reduced by about 38 percent for cars and light-duty trucks and 24 percent for heavy-duty vehicles. ${ }^{34}$ Between 1976 and 1989, about 70 percent of the *313 improvement in fuel economy was due to weight reduction, improvements in transmissions and aerodynamics, the use of front wheel drive, and the use of fuel-injection. ${ }^{35}$

The federal government became concerned with motor vehicle fuel efficiency after the 1973 Mideast oil embargo. The concerns over the nation's petroleum dependence in the mid-1970s became more serious during the following decades. The cost of imported petroleum and the nation's dependency on foreign sources that are often geopolitical adversaries makes the 
nation vulnerable to disruptions in the supply of petroleum. The transportation sector was responsible for 71.4 percent of U.S. petroleum consumption in 2009, and highway vehicles used 84.9 percent of this petroleum. ${ }^{36}$ Oil imports made up 51.9 percent of U.S. petroleum consumption in 2009. ${ }^{37}$ Oil imports were 12.92 million barrels a day in 2008 and 11.72 million barrels a day in $2009,{ }^{38}$ which cost the U.S. economy nearly half a trillion dollars in 2008 and nearly $\$ 300$ billion in $2009 .{ }^{39}$ International relations and diplomacy options are heavily influenced by the nation's dependence on oil, and the outflow of dollars for oil imports is an important component of the U.S. trade deficits. Protecting the Middle East petroleum supply required about $\$ 50$ billion in 2004 to fund such a military mission. ${ }^{40}$ Moreover, increasing worldwide demand is expected to keep upward pressure on oil prices, which will exacerbate the adverse impacts of the nation's dependence on imported oil. ${ }^{41}$

\section{Corporate Average Fuel Economy Standards}

In 1975, Congress enacted the Energy and Policy Conservation Act (EPCA) in response to the oil embargo of 1973-74. ${ }^{42}$ The goals of EPCA are to "decrease dependence on foreign imports, enhance national security, achieve the efficient utilization of scarce resources, and guarantee the availability of domestic energy supplies at prices consumers can afford." 43 Among its provisions were Corporate Average Fuel Economy (CAFÉ) standards that impose a minimum level of average fuel economy applicable to manufacturers of light-duty vehicles for a given model $* 314$ year (MY). ${ }^{44}$ Passenger vehicles are subject to statutory fuel economy standards while non-passenger vehicles must meet standards set by the Department of Transportation's National Highway Traffic Safety Administration (NHTSA). CAFÉ standards began at 18.0 miles per gallon (mpg) for MY 1978 and increased to $27.5 \mathrm{mpg}$ in MY 1985. NHTSA reduced the fuel economy requirements $26.0 \mathrm{mpg}$ in MYs 1986 through 1988, because a drop in gasoline prices had changed consumer demand. ${ }^{45}$ NHTSA's decision was upheld by the D.C. Circuit. ${ }^{46}$ For MY 1989 CAFÉ standards increased to $26.5 \mathrm{mpg}$, and increased again to $27.5 \mathrm{mpg}$ for passenger cars from MY 1990 through MY 2010. ${ }^{47}$ CAFÉ standards became more stringent in MY 2011 and thereafter, which is discussed infra in this section.

Light-duty truck CAFÉ requirements, which are defined to include many SUVs, vans, and pickup trucks, ${ }^{48}$ are set by NHTSA. NHTSA first established light-duty truck standards for MY 1979 for vehicles up to 6,000 pounds gross vehicle weight rating (GVWR) which was increased to 8,500 pounds GVWR for MY $1980 .{ }^{49}$ For MYs 1979-1981, separate standards for two-wheel drive and four-wheel drive vehicles were established. Beginning with MY 1982, an optional combined standard could be used, but NHTSA dropped the separate two-wheel and four-wheel drive standard as an option beginning with MY $1991{ }^{50}$ For MY 1986 through MY 1995 the standard ranged from 20.0 to $20.6 \mathrm{mpg}$ in order to avoid adverse economic impacts on the industry, ${ }^{51}$ which was upheld by the D.C. Circuit. ${ }^{52}$ However, from MY 1996 through MY 2004 Congress limited the standard for light-duty trucks at $20.7 \mathrm{mpg} .{ }^{53}$ After the legislative freeze ended, ${ }^{54}$ NHTSA set more stringent light-duty truck CAFÉ standards in $2003 .{ }^{55} \mathrm{CAFÉ} * \mathbf{3 1 5}$ standards for light trucks increased to $21.0 \mathrm{mpg}$ in MY 2005, $21.6 \mathrm{mpg}$ in MY 2006, 22.2 mpg in MY 2007, $22.5 \mathrm{mpg}$ in MY 2008, 23.1 in MY 2009, and 23.5 in MY 2010. ${ }^{56}$ Vehicles that are not manufactured primarily for highway use and vehicles rated at 10,000 pounds gross vehicle weight or more are excluded from fuel economy regulation because they are not automobiles as defined by the statute. ${ }^{57}$

EPA determines the fuel economy of vehicles using the first 505 seconds of the Federal Urban Driving Simulation cycle, hot started, after a ten-minute hot soak. ${ }^{58}$ This is part of the Federal Test Procedure (FTP) used to quantify a vehicle's emissions, ${ }^{59}$ but the process and calculations are adjusted as specified in the fuel economy regulations. ${ }^{60}$ It is worth noting that most vehicles will achieve higher fuel economy using the U.S. test cycle than would result from using the European or Japanese test procedures. ${ }^{61}$

U.S. cars and light trucks had an actual combined fuel economy of about 25 mpg from 1980 to 2004, and then it began to slowly improve. ${ }^{62}$ The increased sales of light trucks, vans, and SUVs (which have lower mpg and fuel efficiency requirements than regular passenger cars) caused the overall fuel efficiency of the motor vehicle fleet to remain relatively constant for a decade despite improved technology being used on vehicles. ${ }^{63}$ In 1970, light trucks made up 17.4 percent of the nation's vehicle fleet, but in 2008, 44.57 percent of the vehicle fleet was light-duty trucks (including SUVs). ${ }^{64}$ Trucks, including vans and SUVs, made up almost half of the light-duty vehicle sales in 2009. ${ }^{65}$ CAFÉ standards for automobiles are more stringent than the standards for light-duty trucks, which allows SUVs and crossover vehicles to take advantage of the more lenient light-duty truck standards. Sales-weighted fuel economy for new cars was $30.9 \mathrm{mpg}$ in 2008, but it was 22.9 
mpg for light trucks including SUVs. ${ }^{66}$

If a manufacturer fails to meet the fuel economy standard, it is liable to the federal government for a civil penalty of $\$ 5$ for each $0.1 \mathrm{mpg}$, the fleet is above the $* \mathbf{3 1 6}$ standard for each vehicle manufactured ${ }^{67}$ The CAFÉ requirements are separately calculated for domestic and non-domestic manufactured passenger cars and for domestic and non-domestic manufactured light-duty trucks. ${ }^{68}$ However, large manufacturers can manipulate production between these four vehicle classes to avoid violating the law. ${ }^{69}$ In 2008, the total amount of fines for the CAFÉ program was $\$ 12.922$ million. ${ }^{70}$ No major U.S. or Japanese manufacturer has paid a CAFÉ fine related to MY 1983 through MY 2009. Nearly all the money that is collected is from small foreign manufacturers or importers of the cars. ${ }^{71}$

To discourage the purchase of passenger cars that have fuel efficiency less than $22.5 \mathrm{mpg}$, Congress created a gas-guzzler tax in $1978^{72}$ and increased the tax in the Omnibus Budget Reconciliation Act in $1990 .^{73}$ The tax ranges from $\$ 1,000$ for vehicles with a fuel economy rating of 22 to $22.5 \mathrm{mpg}$ up to $\$ 7,700$ for vehicles under $12.5 \mathrm{mpg} .{ }^{74}$ However, it does not apply to trucks, which allows manufacturers and consumers to avoid the tax by purchasing large, fuel-inefficient vehicles that are not subject to the tax. ${ }^{75}$ Nevertheless, tax receipts from the gas-guzzler tax totaled $\$ 172.428$ million in $2008 .{ }^{76}$

On April 6, 2006, the Department of Transportation (DOT) published a final rule imposing new fuel economy standards for sport-utility vehicles, pickup trucks, vans, and minivans beginning with MY $2008 .{ }^{77}$ The rule was projected to result in fuel economy for these vehicles of approximately $24 \mathrm{mpg}$ in MY 2011. ${ }^{78}$ During a transition period, from MY 2008-2010, manufacturers had the choice of complying with CAFÉ standards established under the new structure (reformed CAFÉ) or complying with standards established in the traditional way (unreformed *317 CAFÉ) that were the same as the CAFÉ standards proposed on August 30, 2005. ${ }^{79}$ In MY 2011, the reformed light truck CAFÉ standards impose a fleet-wide average fuel economy standard of 21.8 to $30.4 \mathrm{mpg}$, which applies to all manufacturers. ${ }^{80}$ For passenger cars, the reformed CAFÉ standard for MY 2011 is 30.2 mpg. ${ }^{81}$

The 2006 DOT standards attempt to balance emissions reductions with safety concerns by considering the product of a vehicle's width (distance between tires) and its wheelbase (the distance from the front to the rear axles). ${ }^{82}$ This results in a separate fuel economy standard for each vehicle and the manufacturer must meet a fleet average based on the weighted distribution of its production volumes. ${ }^{83}$ The 2006 rule also expands the applicability of CAFÉ standards to include medium duty passenger vehicles (MDPV) (i.e., larger passenger vans and SUVs with a gross vehicle weight rating of 8,500 to 10,000 lbs) in MY 2011, which DOT estimated would bring an additional 240,000 vehicles into the CAFÉ program. ${ }^{84}$ Pickup trucks and panel trucks are not subject to MDPV requirements. The final rule also states that federal requirements relating to fuel economy preempts any state effort to reduce $\mathrm{CO}_{2}$ emissions from motor vehicles. ${ }^{85}$

In 2007, eleven states, the District of Columbia, New York City, and four national environmental organizations challenged NHTSA's 2006 CAFÉ standards in the Ninth Circuit. ${ }^{86}$ Petitioners claimed the CAFÉ rule ${ }^{87}$ was arbitrary, capricious, and contrary to EPCA, and NHTSA's Environmental Assessment was inadequate under the National Environmental Policy Act. ${ }^{88}$ Petitioners claimed the final rule does not meet EPCA's "maximum feasible" standard, it perpetuates the SUV and minivan loophole that allows light-duty trucks to satisfy lower fuel *318 economy standards, and it excludes most vehicles between 8,500 and 10,000 pounds gross vehicle weight. ${ }^{89}$ Petitioners claimed the rule could lead to increased GHG emissions because vehicle weight classifications that impose lower fuel efficiency requirements for larger vehicles may encourage manufacturers to build larger less fuel-efficient vehicles, and the rule has no guarantee of a minimum average fuel economy or "backstop." 90 They also claimed NHTSA's calculations of costs and benefits failed to assign a value to the benefits of $\mathrm{CO}_{2}$ reduction and failed to evaluate properly the benefit of vehicle weight reduction. ${ }^{91}$

The Ninth Circuit held the final rule is "arbitrary and capricious, contrary to the EPCA in its failure to monetize the value of carbon emissions, failure to set a backstop, failure to close the SUV loophole, and failure to set fuel economy standards for all vehicles in the 8,500 to 10,000 GVWR class." 92 The court held that NHTSA must utilize values for carbon emissions reductions when performing an analysis of the benefits of carbon emissions reductions. ${ }^{93}$ The court found the value of the carbon to be $\$ 50$ a ton according to several studies, including the National Academy of Science study, which translates into a value for carbon emissions of approximately $\$ 0.15$ per gallon of gasoline. ${ }^{94}$ The court rejected NHTSA's assertion that the 
value of reducing $\mathrm{CO}_{2}$ and other GHGs is too uncertain to support explicit valuation and inclusion in evaluating environmental externalities. ${ }^{95}$ The court also held that the Environmental Assessment required by the National Environmental Policy Act was inadequate. ${ }^{96}$ The Ninth Circuit remanded the rule "to NHTSA to promulgate new standards as expeditiously as possible and to prepare a[n] . . Environmental Impact Statement." 97

In 2007, the United States Supreme Court, in a game changing decision, ruled in Massachusetts v. EPA that GHGs are pollutants under the Clean Air Act (CAA). ${ }^{98}$ This means that both the DOT and EPA have a responsibility to regulate $\mathrm{CO}_{2}$ emissions, but it will take several years for EPA to act to regulate $\mathrm{CO}_{2}$.

*319 On December 19, 2007, the Energy Independence and Security Act of 2007 (EISA) was signed into law. ${ }^{99}$ It is applicable beginning with MY 2011 vehicles and requires more stringent CAFÉ standards for passenger vehicles based on regulations to be issued by the Secretary of Transportation. ${ }^{100}$ It mandates a 40 percent increase in fuel economy from cars and light-duty trucks by MY 2020 with one set of standards for passenger vehicles and another set of standards for nonpassenger vehicles. ${ }^{101}$ The law mandates a combined fuel economy of at least $35 \mathrm{mpg}$ for the fleet of vehicles sold in the United States by MY 2020, with civil penalties for non-compliance. ${ }^{102}$ For MY 2021-2030 the fuel economy of each fleet of passenger and non-passenger automobiles sold in the U.S. is to meet the maximum feasible average fuel economy as determined by the Secretary. ${ }^{103}$ Each manufacturer is to meet a minimum standard for domestically manufactured passenger automobiles that is the greater of $27.5 \mathrm{mpg}$ or 92 percent of the average fuel economy projected by the Secretary for the combined domestic and non-domestic passenger automobile fleet for sale in the U.S. by all manufacturers for that model year. ${ }^{104}$ Commercial medium-duty and heavy-duty highway vehicles as well as work trucks with a gross vehicle weight of 8,500 to 10,000 pounds are to have new standards based on the maximum feasible improvement as determined by the Secretary. ${ }^{105}$ The Secretary delegates his or her regulatory responsibility to NHTSA. ${ }^{106}$ The 2007 EISA legislation in $\S 110$ also requires the Administrator of EPA to reevaluate the fuel economy procedures published in 2006 to determine whether a revision is warranted. ${ }^{107}$

*320 Regulations to implement EISA are to be promulgated within two years after a report. ${ }^{108}$ After regulations are promulgated, they will not be applicable for four full model years. ${ }^{109}$ To cover the estimated cost of the CAFÉ provisions, two tax subsidies for the oil and gas industry were removed. ${ }^{110}$ Federal agencies are prohibited from acquiring any light-duty motor vehicle or medium-duty passenger vehicle that is not a low GHG emitting vehicle as defined in the statute, and by 2015 federal agencies are to achieve a 20 percent reduction in annual petroleum consumption. ${ }^{11}$

On May 2, 2008, the Department of Transportation promulgated a proposed rule pursuant to the 2007 EISA that would have imposed fuel economy standards more stringent than those found in the 2007 legislation. ${ }^{112}$ The proposed rule set out standards for MY 2011 through MY 2015 that required cars and light trucks to improve their fuel economy by 4.5 percent a year to reach a MY 2015 standard of 35.7 mpg for automobiles and 28.6 mpg for light trucks. ${ }^{113}$ On January 7, 2009, DOT announced the final rule would not be issued because the financial difficulties of the automobile industry should allow the incoming Obama administration to review the impact of new CAFÉ standards on the industry before promulgating regulations to meet the March 31, 2009 deadline for Fiscal Year (FY) 2011 standards. ${ }^{114}$

On January 26, 2009, President Obama directed NHTSA to issue new fuel economy standards in two parts: 1) MY 2011 standards, and 2) standards for MY *321 2012 and beyond. ${ }^{115}$ The President asked NHTSA to consider climate change issues in making its adjustment to the CAFÉ standards. ${ }^{116}$ NHTSA agreed to consider energy security and climate change in MY 2012 standards, but did not have time to perform a comprehensive evaluation for MY 2011 standards because the required lead-time for the automobile industry required promulgation by March 31, 2009. ${ }^{117}$ NHTSA, in making its decision, monetized energy security values at $\$ 0.29$ per gallon and monetized $\mathrm{CO}_{2}$ reduction at $\$ 7.00$ per ton. ${ }^{118}$ NHTSA promulgated CAFÉ standards for MY 2011 on March 30, 2009. ${ }^{119}$

The MY 2011 standard redefined non-passenger vehicles which resulted in one million vehicles in the light truck fleet being designated passenger cars. ${ }^{120}$ CAFÉ requirements were changed to require MY 2011 passenger cars to meet a $30.2 \mathrm{mpg}$ (294

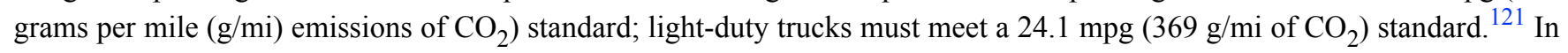


addition, each manufacturer's domestic passenger fleet is required to achieve $27.8 \mathrm{mpg}\left(320 \mathrm{~g} / \mathrm{mi} \mathrm{CO}_{2}\right){ }^{122}$ The MY 2011 CAFÉ standards are the first standards to include a $\mathrm{CO}_{2}$ requirement. However, emissions of $\mathrm{CO}_{2}$ are essentially constant per gallon for a given type of fuel, therefore fuel efficiency standards can be expressed as emission limits for $\mathrm{CO}_{2}{ }^{123}$ This allows NHTSA to indirectly regulate $\mathrm{CO}_{2}$ emissions through the use of CAFÉ standards.

\section{EPA's and NHTSA's Joint $\mathrm{CO}_{2}$ Regulations}

On September 28, 2009, EPA and NHTSA promulgated a proposed joint rule to regulate $\mathrm{CO}_{2}$ emissions and improve fuel economy for MY 2012 through MY 2016 passenger cars, light-duty-trucks, and medium-duty passenger vehicles. ${ }^{124}$ This joint rulemaking effort by NHTSA and EPA aimed to comply with requirements of the 1975 EPCA, as amended by the 2007 EISA, as well as the U.S. Supreme Court's 2007 decision in Massachusetts v. EPA that held GHGs were pollutants based on the definition in CAA $\S 302(\mathrm{~g}){ }^{125}$ However, before GHGs (including $\mathrm{CO}_{2}$ ) could be regulated, EPA had to comply with CAA §202(a)(1), *322 which requires an air pollutant to "reasonably be anticipated to endanger public health or welfare." 126 The Agency must also comply with CAA $\S 201(a)(2)$ when prescribing a regulation by providing the time necessary to develop the requisite technology, "giving appropriate consideration to the cost of compliance within such period."127

On April 17, 2009, the Administrator made a proposed endangerment finding that six GHGs are air pollutants that may be reasonably anticipated to endanger public health and welfare, and four of them $\left(\mathrm{CO}_{2}\right.$, methane, nitrous oxide, and hydrofluorocarbons) are emitted from new automobiles. ${ }^{128}$ EPA's GHG standards for light-duty vehicles, however, could not be finalized until the Agency promulgated the required endangerment finding. On December 15, 2009, EPA promulgated a final rule saying GHG emissions from new motor vehicles contribute to air pollution, and air pollution may reasonably be anticipated to endanger public health and welfare. ${ }^{129}$ This allowed EPA's light-duty vehicle $\mathrm{CO}_{2}$ standard to be finalized.

By mid-January 2010, sixteen lawsuits had been filed in the D.C. Circuit challenging the endangerment finding. ${ }^{130}$ The court postponed the cases to allow EPA to respond to ten administrative petitions that had been filed with EPA. ${ }^{131}$ The Agency denied the petitions for review, and on August 13, 2010, the U.S. Chamber of Commerce filed a suit in the D.C. Circuit challenging the legality of EPA's rejection of the administrative petition. ${ }^{132}$ On December 10, 2010, the D.C. Circuit denied the motion to stay and ordered the case to be scheduled for oral argument. ${ }^{133}$ On January 21, 2010, Senator Lisa Murkowski (R-Alaska) introduced a resolution, S.J. Res. 26, seeking to nullify EPA's endangerment finding. She had *323 substantial Republican support, but needed to obtain support from Democrats if she were to achieve the necessary fifty-one votes. ${ }^{134}$ This resolution was voted down in the Senate in June 2010, in a 53-47 vote, although six Democrats supported the resolution. 135 On February 2, 2010, Rep. Ike Skelton (D-Mo.) introduced H.R. 4572 to repeal EPA's authority to regulate GHG emissions under the CAA. ${ }^{136}$

On May 7, 2010, EPA and NHTSA promulgated a final joint rule applicable to light-duty vehicles for MY 2012 through MY $2016 .{ }^{137}$ Vehicles covered by this rule are responsible for almost 60 percent of the transportation-related GHG emissions. ${ }^{138}$ This rule is projected to reduce GHGs from the U.S. light-duty fleet by approximately 21 percent by 2030 from what would occur without this rule. ${ }^{139}$ An additional goal of the rule is to create one standard that would be accepted by California and other states that have worked to create more stringent motor vehicle fuel efficiency standards. ${ }^{140}$ This resulted in the automobile industry dropping lawsuits opposing the California standards, which have been adopted by thirteen other states.

${ }^{141}$ However, industry groups are challenging the May 7, 2010 rule in the D.C. Circuit. ${ }^{142}$

EPA's MY 2012 through MY 2016 regulations are based on its CAA $\S 202$ authority; NHTSA's standards are based on its authority under 49 U.S.C. $§ 32902$. EPA's standards require light-duty vehicles to meet an estimated combined *324 average emissions level of $250 \mathrm{~g} / \mathrm{mi}$ in MY 2016, which is equivalent to a combined average fuel economy of $35.5 \mathrm{mpg}$, if the standard is met solely through fuel economy improvements. ${ }^{143}$ NHTSA's standards would require a combined average lightduty vehicle fuel economy that becomes increasingly stringent from MY 2012 until it reaches $34.1 \mathrm{mpg}$ in MY $2016 .{ }^{144}$ The reason for the small difference in the standards is due to the differences in the statutes under which the two agencies operate. This resulted in slightly higher fuel efficiency requirements under EPA's regulation because EPA expects manufacturers to 
obtain $\mathrm{CO}_{2}$ credits for reductions in emissions of GHGs due to improvements in air conditioner systems. Such credits are not available under the laws that are applicable to NHTSA. ${ }^{145}$ NHTSA's CAFÉ standards for passenger cars are projected to increase from 33.3 to $37.8 \mathrm{mpg}$ over five years, and light-duty trucks will go from 25.4 to $28.8 \mathrm{mpg}$, which is an average annual increase in fuel efficiency of 4.3 percent relative to MY 2011 standards. ${ }^{146}$ Each manufacturer must meet a standard determined using a sales-weighted average for the various passenger cars and light-duty trucks. Light-duty trucks require a 3.4 percent annual improvement, while cars must increase fuel efficiency by 4.5 percent per year. ${ }^{147}$ The fleet fuel economy that is achieved will depend on the mix of vehicles sold, the extent to which flex fuel credits are used, and the extent to which manufacturers choose to pay civil penalties rather than achieve the regulatory requirements. ${ }^{148}$

On May 21, 2010, President Obama requested that the Secretaries of Transportation and Energy and the Administrators of EPA and NHTSA issue a Notice of Intent to Issue a Propose Rule for the MY 2017-MY 2025 vehicles by September 30, $2010 .{ }^{149}$ It is to be harmonized with applicable State standards to assure that automobile manufacturers will be able to build a single, light-duty national fleet. ${ }^{150}$ EPA and NHTSA are requested to work with the State of California to assess the factors needed to accomplish this task by September 1, $* 3252011 .{ }^{151}$ On October 13, 2010, EPA and NHTSA published a notice of intent to conduct joint rulemaking. ${ }^{152}$ The notice explained the agencies approach and said the MY 2025 targets were analyzed using four potential GHG reduction targets of 3, 4, 5, and 6 percent per year from the MY 2016 fleet-wide average of $250 \mathrm{~g} / \mathrm{mi}^{153}$ The 6 percent annual reduction would produce a fleet average of $62 \mathrm{mpg} .{ }^{154}$ This proposal is supported by environmental groups but is criticized by the automobile industry (which did not object to the MY 2016 regulations). ${ }^{155} \mathrm{~A}$ supplemental notice in November 2010 announced that EPA and NHTSA expect to issue a proposed rulemaking by September 30, 2011, and a final rulemaking by July 31, 2012. ${ }^{156}$

\section{Heavy-Duty Truck Proposed Standards}

On May 21, 2010, President Obama announced NHTSA and EPA are to initiate two joint rulemakings. ${ }^{157}$ The first rule will focus on improved fuel efficiency and reduced GHG emissions from heavy-duty vehicles. ${ }^{158}$ The second rule, previously discussed, will impose more stringent standards for improved fuel efficiency and GHG reductions from MY 2017 and thereafter in light-duty vehicles. ${ }^{159}$ EPA and NHTSA responded in October 2010 with an announcement of a "first-ever program to reduce [GHG] emissions and improve fuel efficiency of medium- and heavy-duty vehicles." 160 On November 30, 2010, EPA and NHTSA *326 promulgated the proposed rule. ${ }^{161}$ It is "designed to address the urgent and closely intertwined challenges of dependence on oil, energy security, and global climate change." 162 The proposed rule represents "the first time that NHTSA and EPA would regulate the heavy-duty sector for fuel consumption and GHG emissions, respectively." 163

Heavy-duty trucks that range from 18-wheelers to the largest pickups are the second largest source of transportation petroleum consumption and are responsible for about 20 percent of U.S. GHG emissions. ${ }^{164}$ "Heavy-duty trucks have always been an important part of the goods movement infrastructure in this country and have experienced significant growth over the last decade related to increased imports and exports of finished goods and increased shipping of finished goods to homes through Internet purchases." 165

NHTSA proposed a fuel consumption standard and EPA proposed a $\mathrm{CO}_{2}$ standard applicable to the three regulatory categories: (1) combination tractors; (2) heavy-duty pickup trucks and vans; and (3) vocational vehicles, as well as gasoline and diesel heavy-duty engines. ${ }^{166}$ In addition, EPA is proposing hydrofluorocarbon emissions standards for air conditioning systems in tractors, pickup trucks, and vans; and nitrous oxide $\left(\mathrm{N}_{2} \mathrm{O}\right)$ and methane $\left(\mathrm{CH}_{4}\right)$ emissions standards are proposed for heavy-duty engines, pickup trucks, and vans. ${ }^{167}$ EPA's standards would begin with MY 2014 vehicles; NHTSA's proposed fuel consumption standards would be voluntary in MY 2014 and MY 2015, in order to provide the four full model years of regulatory lead-time required by EISA, and would become mandatory in MY 2016, for most regulatory categories. 168 The heavy-duty category is defined to include all on-road vehicles rated at a GVWR of 8,500 pounds or more, except medium-duty vehicles covered by the current CAFÉ standards for MY 2012-MY 2016 light-duty vehicles. ${ }^{169}$ EPA is including *327 recreational on-highway vehicles within its rulemaking, but NHTSA is not, because its statutory authority is limited to regulating commercial vehicles. ${ }^{170}$ 
The proposed rule covers the complete vehicle, not just engines. ${ }^{171}$ "Congress emphasized that the test methods, measurement metrics, standards, and compliance and enforcement protocols must all be appropriate, cost-effective, and technologically feasible for commercial medium-duty and heavy-duty on-highway vehicles and work trucks." ${ }^{172}$ NHTSA and EPA interpret heavy-duty vehicle fuel economy standards more broadly than the miles per gallon approach used with lightduty vehicles by focusing on the work done with these vehicles and their overall fuel efficiency. ${ }^{173}$

NHTSA and EPA may create separate standards for different classes of heavy-duty vehicles, ${ }^{174}$ which the agencies interpret broadly to allow regulation of heavy-duty engines in addition to heavy-duty vehicles. Regulating heavy-duty engines is based on the fact that there are a relatively small number of heavy-duty engine designs used in an extremely wide range of truck designs. ${ }^{175}$ There are seven categories of heavy-duty trucks (Classes $2 \mathrm{~b}$ through 8 ) used by various federal agencies based on their gross combined weight rating (GCWR), categorized by the maximum load that the vehicle can haul, including the weight of a loaded trailer and the vehicle itself. ${ }^{176}$ The first two weight classes ( $2 \mathrm{~b} \& 3$ ) are primarily work trucks and vans. 177 The remaining categories are used for cargo carrying or specialized use vehicles (e.g, fire trucks). ${ }^{178}$ The last two categories $(7 \& 8)$ are combination tractor-trailers. ${ }^{179}$ "A relatively limited number of manufacturers produce the vast majority of" heavy-duty tractors and engines, but the trailer manufacturing industry "includes a large number of companies, many of which are relatively small in size and production volume." ${ }^{\prime 180}$ For this reason, the trailers that are attached to the tractors are exempted from regulation at this time. ${ }^{181}$

NHTSA and EPA propose to divide heavy-duty trucks into three regulatory categories: heavy-duty pickups and vans, combination tractors, and vocational $* \mathbf{3 2 8}$ vehicles. ${ }^{182}$ Vocational vehicles can be found in any weight category, "including smaller and larger van trucks, utility 'bucket' trucks, tank trucks, refuse trucks, urban and over-the-road buses, fire trucks, flat-bed trucks, and dump trucks, among others." 183 For vocational vehicles, there are two sets of standards to achieve reductions in GHG emissions and fuel consumption through both engines and the vehicle body. ${ }^{184}$ The first set of standards addresses engines. ${ }^{185} \mathrm{EPA}$ is proposing $\mathrm{CO}_{2} \mathrm{~g} /$ ton-mile standards (the mass of emissions from carrying a ton of cargo over a distance of one mile), and NHTSA is proposing fuel consumption standards of gal/1,000 ton-mile (gallons of fuel consumed over a set distance of 1,000 miles with a one ton payload), for chassis manufacturers. ${ }^{186}$ The second set of standards involves requirements for vehicle body manufacturers and would be limited to tire improvements because at this time that is the primary means of vehicle body improvement available. ${ }^{187}$

Heavy-duty vehicles with GVWR between 8,501 and 10,000 $\mathrm{lb}$ are classified as Class $2 \mathrm{~b}$ motor vehicles, which includes MDPVs that will continue to be regulated under the light-duty vehicle program. ${ }^{188}$ Heavy-duty vehicles with GVWR between 10,001 and 14,000 lb are classified as Class 3 motor vehicles. About 90 percent of the Class $2 \mathrm{~b}$ and Class 3 pickups and vans are 3/4-ton and 1-ton pickup trucks, 12- and 15-passenger vans, and large work vans that are sold by vehicle manufacturers as complete vehicles. ${ }^{189}$ Over 95 percent of the heavy-duty pickups and vans sold in the United States are manufactured by Ford, General Motors, and Chrysler. ${ }^{190}$ EPA proposes GHG standards for these vehicles in grams per mile (g/mile), the way they are regulated by EPA for criteria pollutants. ${ }^{191}$ NHTSA is proposing a similar standard expressed as gallons of fuel consumed per 100 miles. ${ }^{192}$ These light-duty GHG and fuel economy standards factor in vehicle size by basing the emissions and fuel economy targets on vehicle footprint (the wheelbase times the average track width). ${ }^{193}$ Each manufacturer will be required to meet a fleet average standard based on production volume-weighting of target standards for each vehicle, which are based on the vehicle's work factor. ${ }^{194}$

For combination tractors and vocational trucks, EPA's proposed standards are in the form of the mass of emissions from carrying a ton of cargo over a distance $* \mathbf{3 2 9}$ of one mile (g/ton-mi). ${ }^{195}$ The proposed NHTSA standards are in terms of gallons of fuel consumed over a set distance (gal/1,000 ton-mile). ${ }^{196}$ For combination tractors (weight class $7 \& 8$ ), nine subcategories have been created based on weight, cab type, and roof height. ${ }^{197}$ Combination trailers are subject to two sets of standards. The tractor manufacturer must meet vehicle-based standards that include consideration of aerodynamic features, weight reductions, tire rolling resistance, the presence of idle-reducing technology, vehicle speed limiters, driveline losses and auxiliary power demand (e.g. heating and air conditioning). ${ }^{198}$ EPA is also proposing a standard applicable to tractor manufacturers to limit leakage of HFC refrigerant from cabin air conditioning systems. ${ }^{199}$

The agencies are proposing separate performance standards for the engines manufactured for use in these trucks. ${ }^{200}$ For 
heavy-duty engines, EPA is proposing standards in the form of grams per brake horsepower-hour grams (g/bhp-hr), which is emissions per unit of work and is the approach used for regulating criteria pollutants emitted from heavy-duty highway engines. ${ }^{201}$ Similarly, NHTSA proposed standards for heavy-duty engines are in the form of gallons of fuel consumption per 100 units of work (gal/100 bhp-hr). ${ }^{202}$ Standards for $\mathrm{CO}_{2}$ and fuel consumption, as well as $\mathrm{N}_{2} \mathrm{O}$ and $\mathrm{CH}_{4}$, emissions, are proposed for the engines used in these trucks. ${ }^{203}$ It is expected that these requirements will be met through the use of improved turbochargers, after-treatment optimization, low temperature exhaust gas recirculation, and engine friction reductions. $^{204}$

*330 EPA and NHTSA estimate the net benefits of the heavy-duty vehicle regulations at $\$ 27$ billion to $\$ 41$ billion, based on a social value of carbon (SCC) and using a discount rate of 7 percent and 3 percent for MY 2014-2018 heavy-duty vehicles. ${ }^{205}$ EPA standards proposed for 2018 (including a separate standard to control air conditioning system leakage) are projected to reduce average per-vehicle emissions of GHGs by 17 percent for diesel vehicles and 12 percent for gasoline vehicles, compared to a common baseline. ${ }^{206}$ EPA and NHTSA expect that the new tractor cab and separate standard for the engines installed in the tractor will reduce fuel consumption up to 20 percent by $2018 .{ }^{207}$ The agencies project that by 2020 the program will result in no cost or negative costs because fuel savings will offset the costs. ${ }^{208}$ For vocational vehicles and combination tractors, payback periods are much shorter and actually are expected to occur within the first year of ownership because these trucks travel more miles in a given year. ${ }^{209}$ In addition to the benefits to heavy-duty truck operators, EPA estimates the proposed rule will reduce oil imports by 0.177 million barrels per day in 2020 and will increase to 0.463 million barrels per day in $2040 .^{210}$

\section{California's Control of Mobile Source GHG Emissions}

When Congress, in 1967, preempted the control of emissions from new motor vehicles in the CAA, it exempted California by creating a statutory exemption for any state that regulated automobile emissions "prior to March 30, 1966." 211 The CAA of 1970 continued the California exemption in section 209, which in 1977 was amended to require EPA to consider California's standards as a package and waive federal preemption if the state determines that the standards "in the aggregate" protect public health at least as well as the federal standards. ${ }^{212}$ EPA's power to deny a waiver is limited; the waiver is to be approved unless the Administrator finds: (1) the determination of the state is arbitrary and capricious; (2) the state does not need such a standard to meet compelling and extraordinary conditions; or (3) the state standards are not consistent with CAA $\S 202(a) .{ }^{213}$ The 1977 CAA Amendments added CAA $\S 177$, which allows states with nonattainment areas to adopt California standards for which a waiver had been granted, if such states adopt identical standards and provide at least a two year $* \mathbf{3 3 1}$ grace period before compliance is required. ${ }^{214}$ This has resulted in decades of litigation as states attempted to adopt California standards and the automotive industry resisted. ${ }^{215}$

In 1990, the California Air Resources Board (CARB) first adopted a "Low Emission Vehicle/Clean Fuels" (LEV/CF) program that imposed standards from 1994 through 2003. ${ }^{216}$ In 1999, CARB amended LEV regulations to create LEV II regulations that were applicable from 2004 through $2010 .^{217}$ The LEV II program increased the stringency of emission reduction requirements and expanded passenger car requirements to include vehicles up to 8,500 pounds gross vehicle weight (GVW), which made most SUVs and pickup trucks subject to passenger car standards. ${ }^{218}$ Moreover vehicles classified as medium-duty $\left(8,501-14,000\right.$ pounds GVW) had standards almost as stringent as passenger cars. ${ }^{219}$ LEV II created a new category of super-ultra low emission vehicles (SULEV) for vehicles that only emit one pound of hydrocarbons in 100,000 miles of driving. ${ }^{220}$ The category of zero emission vehicles (ZEVs) for vehicles with near zero emissions was modified to give partial ZEV credits of 0.7 for methanol reformer fuel cell vehicles, 0.4 for compressed natural gas SULEV and 0.2 for a gasoline fueled SULEV. 221

In 2002, the California legislature imposed $\mathrm{CO}_{2}$ emission limits on motor vehicles. ${ }^{222}$ The law required CARB to promulgate and implement rules that would reduce $\mathrm{CO}_{2}$ emissions from cars and light-duty trucks by 22 percent from the 2002 level by 2009, and reduce $\mathrm{CO}_{2}$ emissions by 30 percent by MY 2016. ${ }^{223}$ In 2005 CARB formally adopted GHG regulations. ${ }^{224}$ The regulations needed to be approved by EPA, which must grant a waiver if the statutory requirements are met; EPA has granted about 50 new waivers since 1968 and denied five. ${ }^{225}$ California applied for a waiver in December 1, 2005, pursuant to CAA 
$\S 209(\mathrm{~b}){ }^{226}$

*332 Automobile dealers and manufacturers then litigated in California to prevent imposition of fuel-economy standards more stringent than federal requirements, based on claims that the federal fuel economy standards preempt the field. ${ }^{227}$ The court held the regulations are emission standards and thus are preempted under CAA $\S 209$ (a) unless EPA grants a $\S 209$ (b) waiver. However, the court placed the case on hold until the Supreme Court could decide Massachusetts v. EPA. ${ }^{228}$ Before the waiver issue could be resolved, on March 27, 2008, CARB reduced the number of ZEVs that must be sold in the three years beginning in 2012 but created new requirements for producing partial ZEVs. ${ }^{229}$ Automakers were to sell or lease 7,500 hydrogen fuel cell or battery-powered vehicles and sell or lease 60,000 plug-in hybrid vehicles between 2012 and $2014 .^{230}$

The Supreme Court's 2007 decision that held GHGs to be pollutants under the CAA also approved the use of overlapping fuel economy standards by EPA and DOT, which increased the pressure on EPA to issue a waiver to California. ${ }^{231}$ Nine northeastern states (Connecticut, Maine, Maryland, Massachusetts, New Jersey, New York, Pennsylvania, Rhode Island, and Vermont), as well as Arizona, Florida, New Mexico, Oregon and Washington D.C. had adopted California's standards pursuant to CAA $\S 177 .{ }^{232}$ Their standards, however, were not enforceable until California received a waiver from EPA allowing the standards to be implemented. The waiver was denied by EPA in March 2008 based on EPA's conclusion that the situation did not meet the CAA's requirement that there be "compelling and extraordinary conditions." ${ }^{233}$ This denial prevented the fourteen other states that have adopted California's GHG regulations from implementing their programs. ${ }^{234}$ This denial was followed by years of litigation that ended with a May 7, 2010 agreement that resolved the issues. ${ }^{235}$

*333 On January 26, 2009, President Obama directed EPA to reconsider the Bush Administration's decision that barred California and other states from regulating GHG emissions from motor vehicles. ${ }^{236}$ On June 30, 2009, EPA granted California a waiver that allows it to implement GHG reduction standards for passenger cars, pickup trucks and sport utility vehicles. ${ }^{237}$ On September 24, 2009, CARB adopted amendments to its regulations to reduce GHG emissions from new passenger vehicles from 2012 through 2016. ${ }^{238}$ EPA's waiver and California's adoption of regulations will now allow more than a dozen states to implement the California standards. ${ }^{239}$

CARB's requirements are based on the "fleet average" for two categories of vehicles: (1) passenger vehicles and light-duty trucks under 3,750 pounds are classified as Light Duty Vehicles; and (2) light-duty trucks over 3,750 pounds and medium duty passenger vehicles are classified as light-duty trucks (LDTs). ${ }^{240} \mathrm{CARB}^{\prime} \mathrm{CO}_{2}$ regulations commenced with MY 2009 vehicles and aimed to reduce $\mathrm{CO}_{2}$ by about 25 percent for cars and LDTs and 18 percent for larger trucks and sport utility vehicles. $^{241}$ The second phase, targeted for 2013 to 2016, would require a 34 percent reduction for cars and LDTs and a 25 percent reduction for larger vehicles. ${ }^{242}$ Manufacturers that meet or exceed the requirements receive credits that may be used to offset a manufacturer's emissions for up to five years. ${ }^{243}$

The Obama administration promulgated more stringent national fuel economy and GHG vehicle standards on May 7, 2010, for MY 2012 to MY 2016, which are discussed supra in $\S 3 .{ }^{244}$ This provides California the standards it sought to impose, although CARB had to modify its 2009-2011 standards to allow compliance based on a fourteen state vehicle fleet rather than just using a California vehicle fleet average. The federal rule allows automakers to meet the $* \mathbf{3 3 4}$ California standard by complying with the national standard. ${ }^{245}$ In return the automakers agreed to drop their GHG lawsuits. ${ }^{246}$

California's Global Warming Solutions Act of 2006 (Assembly Bill 32) seeks to reduce GHGs in a cost-effective manner by creating a market for cleaner vehicles, requiring low-carbon fuels, mandating renewable electricity, and imposing energy efficiency standards. ${ }^{247} \mathrm{~A}$ cap-and-trade program to control emissions from sources of 85 percent of California's GHG emissions is an important part of the state's GHG reduction strategy. ${ }^{248}$ It requires sources of GHGs to have an allowance for each metric ton of carbon dioxide equivalent $\left(\mathrm{MtCO}_{2} \mathrm{e}\right)$ released. ${ }^{249}$ Most of the allowances will be given without charge. ${ }^{250}$ By limiting the number of allowances issued in the state, and by reducing the number of allowances over time, the aggregate statewide emissions should be lowered.

California's program is to begin in 2012 with coverage of electricity generated in the state, those who deliver imported electricity to the California electric grid, and large industrial sources with annual GHG emissions at or above 25,000 
$\mathrm{MtCO}_{2} \mathrm{e} .{ }^{251}$ In 2015, the program is to expand to cover fuels used for transportation. ${ }^{252}$ Initially, the cap is set at the level of emissions expected in 2012, which is 165.8 million $\mathrm{MtCO}_{2} \mathrm{e}$ and it declines in 2013 and 2014. In 2015, the cap increases to 394.5 $\mathrm{MtCO}_{2} \mathrm{e}$ because fuels are to be covered, and the cap then declines in 2016 to $2020 .{ }^{253}$ The program is based on a three-year compliance period with annual surrendering of allowances to equal the total allowable GHG emissions. ${ }^{254}$

*335 The California cap-and-trade rules came to a final vote by CARB on December 16, 2010. ${ }^{255}$ However, the future of GHG control in California was placed in doubt by Proposition 23, which was on the November 2, 2010 California ballot. ${ }^{256}$ It would have suspended the Global Warming Act of 2006 until California's unemployment rate dropped below 5.5 percent for four consecutive quarters. ${ }^{257}$ Because the State's unemployment rate is about 12 percent, Proposition 23 was designed to end GHG control in California, but it was defeated by a vote of 61.5 percent to 38.5 percent. ${ }^{258}$ The attempt to end the application of the Global Warming Act of 2006 was heavily financed by out-of-state companies, particularly Valero Energy and Tesoro Corporation that are Texas oil companies. ${ }^{259}$ A more serious problem for GHG regulation now flows from Proposition 26, also on the November 2, 2010 ballot and actually approved. Proposition 26 requires legislative approval by a two-thirds vote to impose certain state and local fees. ${ }^{260}$ Fees include charges that address adverse impacts on society or the environment caused by the fee-payer's business. This proposition passed with 52.5 percent of the vote and may apply to a cap-and-trade program. ${ }^{261}$ The measure will make it more difficult to impose regulatory fees, such as environmental clean-up fees, and it will increase the uncertainty concerning whether a measure is a tax or a fee that can be expected to lead to litigation. This proposition was supported by the tobacco, alcoholic beverage, and oil industries. ${ }^{262}$

Since President Obama took office, EPA's approach to California's effort to impose more stringent emission standards has been to create more stringent federal standards. California however continues to pressure EPA. EPA has provided notice that it will issue standards for MY 2017-2025 vehicles. ${ }^{263}$ Federal proposed standards are expected to be promulgated in the fall of 2011 and finalized in July 2012, but California is scheduled to propose MY 2017-2025 standards in *336 September 2011 and it is expected that they will be the same as federal standards that will also be proposed in September 2011. ${ }^{264}$

\section{Conclusion}

In the absence of a major effort to control mobile source GHGs, emissions will continue to increase in the United States because of growth in population and VMT. However, impressive efforts are underway to arrest and perhaps lower emissions from the transportation sector. There are more than 35 vehicles presently being marketed in the U.S. that achieve $35 \mathrm{mpg}$, or better, based on EPA's 2011 highway fuel economy test. ${ }^{265}$ But not enough of these vehicles are purchased to prevent motor vehicle $\mathrm{CO}_{2}$ emissions from increasing. For the period 1970 to 2009, U.S. transportation petroleum consumption by the transportation sector increased by 1.3 percent a year, but the increase in petroleum consumption by the transportation sector has been slowing, and from 1999 to 2009 consumption increased annually at only 0.2 percent. ${ }^{266}$ This resulted in a 2.02 million gallon per day increase in U.S. transportation fuel consumption in the 1990 to 2009 period, although in 2008 and 2009 petroleum consumption dropped. ${ }^{267}$

Programs to reduce emissions of GHGs through increasingly stringent CAFÉ standards are more politically feasible than increasing gasoline taxes or imposing fees on fuel-inefficient vehicles, although a mix of many different measures would probably be the most effective way to reduce GHG emissions. Petroleum demand could be reduced if the cost of driving increased significantly through the use of a carbon tax or by increasing gasoline taxes or by using other economic disincentives. Compared to other developed nations, fuel taxes in the United States are low. State taxes on gasoline averaged 29.7 cents per gallon (cpg) in the last quarter of 2010, and the federal excise tax of $18.4 \mathrm{cpg}$ brings the total tax to $48.1 \mathrm{cpg}$. State taxes on diesel fuel averaged $28.7 \mathrm{cpg}$, and the federal tax of $24.4 \mathrm{cpg}$ brings the total to $53.1 \mathrm{cpg}$. ${ }^{268}$ These taxes have been inadequate to maintain the highway system and will become more inadequate if fuel economy increases significantly. Taxes have the advantage of being quick to implement and because of the limited number of refineries the costs of administering the program are low and compliance rates are high. CAFÉ standards have delayed benefits because of the necessity to provide manufacturers with adequate time to meet the standard. *337 Moreover, without high fuel costs, it is difficult to get consumers to buy fuel-efficient vehicles.

The use of hybrid vehicles can lower fossil fuel consumption, and the sale of hybrids would benefit from more generous tax 
incentives for those purchasing these vehicles. But the disadvantage of this approach is that it distorts the free market and discourages research and development of fuel-efficient vehicles that do not use hybrid technology. For this reason in the long run it may be beneficial that the tax credit for buying a hybrid has been phased out for vehicles purchased after December 31, $2010 .{ }^{269}$ While hybrids offer improved fuel economy, they are only a transition technology until plug-in hybrid vehicles and other advanced technologies are commercially available. ${ }^{270}$ Nevertheless, it may be the use of improved conventional technology, especially technology that reduces the weight of vehicles, which will prove to be the most cost-effective way to improve motor vehicle fuel economy. ${ }^{271}$

The program to increase motor vehicle fuel efficiency is an important step in the right direction. Unlike the programs to control stationary sources, the fuel economy improvements required in the recent EPA/NHTSA rules have little or no net cost because the cost of compliance is offset by the reduced cost of fuel. Moreover, the rules should help reduce the growth in petroleum imports that adversely affect the nation's trade balance and makes the nation a hostage to oil producing nations. These rules do not materially expand the size or the power of the federal government, and they have low transactional costs. Finally, the more stringent fuel economy standards appear to have the support of both industry and environmental groups. ${ }^{272}$

\begin{tabular}{|c|c|}
\hline \multicolumn{2}{|c|}{ Footnotes } \\
\hline a1 & $\begin{array}{l}\text { (C) } 2011 \text { Arnold W. Reitze. Professor of Law, S.J. Quinney College of Law, University of Utah, and member of the University } \\
\text { of Utah's Institute for Clean \& Secure Energy; J.B. and Maurice Shapiro Professor Emeritus of Environmental Law, The } \\
\text { George Washington University. The author wishes to express his appreciation to Marie Bradshaw Durrant, J.D., PhD, for her } \\
\text { review of the manuscript. arnold.reitze@law.utah.edu. }\end{array}$ \\
\hline 1 & $\begin{array}{l}\text { Michael Pidwirny, Atmospheric Composition, Fundamentals of Physical Geography (2d ed. 2009), PhysicalGeography.net, } \\
\text { http:// www.physicalgeography.net/fundamentals/7a.html. }\end{array}$ \\
\hline 2 & $\begin{array}{l}\text { Carbon Dioxide, Methane Rise Sharply in 2007, Nat'l Oceanic and Atmospheric Admin. (Apr. 23, 2008) http:// } \\
\text { www.noaanews.noaa.gov/stories2008/20080423_methane.html. }\end{array}$ \\
\hline 3 & $\begin{array}{l}\text { Stacy C. Davis, Susan W. Diegel \& Robert G. Boundy, U.S. Dept. of Energy, ORNL-6985, Transportation Energy Data Book } \\
11-2 \text { tbl.11.1 (29th ed. 2010). }\end{array}$ \\
\hline 4 & $\begin{array}{l}\text { U.S. Envtl. Prot. Agency, Inventory of U.S. Greenhouse Gas Emissions and Sinks: 1990-2008 ES-6 (2010), available at } \\
\text { http:// www.epa.gov/climatechange/emissions/downloads10/US-GHG-Inventory-2010_ Report.pdf [hereinafter EPA } \\
\text { Inventory]. }\end{array}$ \\
\hline 5 & $\begin{array}{l}\text { Id. at ES-4, tbl.ES-2. In addition, } 567.6 \text { million metric tons of methane }\left(\mathrm{CO}_{2} \text { equivalent), } 318.2 \text { million metric tons of } \mathrm{N}_{2} \mathrm{O}\right. \\
\left(\mathrm{CO}_{2 \mathrm{e}}\right) \text { and much smaller amounts of the other GHGs were emitted. Id. Since } 1990 \text { methane and nitrous oxide emissions have } \\
\text { decreased, but } \mathrm{CO}_{2} \text { emissions have increased by an annual average of } 0.85 \text { percent. Id. }\end{array}$ \\
\hline 6 & $\begin{array}{l}\text { Davis, Diegel \& Boundy, supra note } 3 \text {, at } 11-6 \text { tbl.11.5. The other sectors are residential, commercial, and industrial. Id. } \\
\text { Although electric power production is the largest single source of } \mathrm{CO}_{2} \text { emissions, it is not considered an end-use, therefore, } \\
\text { its emissions are allocated by the federal government to the four economic sectors. Electricity used by the transportation } \\
\text { sector is a nominal } 0.3 \text { percent of the sector's total energy demand. Id. at } 11-7 \text { tbl.11.6. }\end{array}$ \\
\hline 7 & See EPA Inventory, supra note 4 , at ES-4 tbl.ES-2 (calculated from data in the table). \\
\hline 8 & Davis, Diegel \& Boundy, supra note 3, at 11-7, tbl.11.6. \\
\hline 9 & Id. at $12-1$. \\
\hline 10 & See generally Arnold W. Reitze, Jr., Air Pollution Control and Climate Change Mitigation Law, Chapter 11 (2d ed. 2010). \\
\hline
\end{tabular}




\begin{tabular}{|c|c|}
\hline 11 & Id. \\
\hline 12 & Edward F. Obert, Internal Combustion Engines and Air Pollution 87 (Intex Educational Pub., 3d ed. 1973). \\
\hline 13 & Id. at $478-79$. \\
\hline 14 & $\begin{array}{l}\text { If adequate air is available for complete combustion all the carbon in the fuel is transformed into carbon dioxide. D.J. } \\
\text { Patterson \& N.A. Henein, Emissions from Combustion Engines and Their Control } 68 \text { (1972). }\end{array}$ \\
\hline 15 & $\begin{array}{l}\text { See generally Nic Lutsey, Powerpoint Presentation, Technologies and Trends for Reducing Automobile Greenhouse Gas } \\
\text { Emissions in the } 2025 \text { Timeframe, Cal. Air Res. Bd. (Mar. 2, 2010), http:// www.arb.ca.gov/msprog/levprog/leviii/meetings/ } \\
\text { 030210/lutsey_ghg_mar2_arb_workshop.pdf. }\end{array}$ \\
\hline 16 & See generally John B. Rae, The American Automobile (Daniel J. Boorstin, ed., 1965). \\
\hline 17 & Davis, Diegel \& Boundy, supra note 3, at 10-19, tbl.10.17. \\
\hline 18 & See generally John B. Rae, The Road and the Car in American Life (1971). \\
\hline 19 & Fiscal Year 2010, Budget Highlights, U.S. Dep’t of Transp. (May 2009), http://www.dot.gov/budget/2010/bib2010.htm. \\
\hline 20 & Id. \\
\hline 21 & $\begin{array}{l}\text { See, e.g., Gabriel Roth, Federal Highway Funding, CATO Institute (June 2010), http://www.downsizinggovernment.org/ } \\
\text { transportation/highway-funding. }\end{array}$ \\
\hline 22 & $\begin{array}{l}\text { See, e.g., Times Topics: Automotive Industry Crisis, N.Y. Times, http://topics.nytimes.com/top/reference/timestopics/ } \\
\text { subjects/c/credit_crisis/auto_industry/index.html (last updated June 25, 2011). }\end{array}$ \\
\hline 23 & Davis, Diegel \& Boundy, supra note 3, at 8-3 tbl.8.2. \\
\hline 24 & Id. \\
\hline 25 & Id. at $8-3$ tbl.8.2. \\
\hline 26 & Id. at $8-2$ tbl.8.1. \\
\hline 27 & Id. \\
\hline 28 & $\begin{array}{l}\text { See Arnold W. Reitze, Jr., Electric Power in a Carbon Constrained World, } 34 \text { Wm. \& Mary Envtl. L. \& Pol'y Rev. 821, } \\
\text { 893-927 (2010). }\end{array}$ \\
\hline 29 & $\begin{array}{l}\text { Inflation Adjusted Gasoline Prices, InflationData.com, http:// www.inflationdata.com/inflation/inflation_rate/ } \\
\text { Gasoline_Inflation.asp (last updated July 21,2010). }\end{array}$ \\
\hline 30 & $\begin{array}{l}\text { See Robert A. Johnston, Victoria Transp. Pol'y Inst., Review of U.S. and European Regional Modeling Studies of Policies } \\
\text { Intended to Reduce Motorized Travel, Fuel Use, and Emissions } 3 \text { (2006), available at http:// www.vtpi.org/johnston.pdf. }\end{array}$ \\
\hline
\end{tabular}




\begin{tabular}{|c|c|}
\hline 31 & $\begin{array}{l}\text { National Commission on Energy Policy, Effectiveness and Impact of Corporate Average Fuel Economy (CAFE) Standards } \\
\text { (2004). }\end{array}$ \\
\hline 32 & Id. at 23 . \\
\hline 33 & $\begin{array}{l}\text { David L. Greene \& Andreas Schafer, PEW Ctr. on Global Climate Change, Reducing Greenhouse Gas Emissions from U.S. } \\
\text { Transportation } 22(2003) .\end{array}$ \\
\hline 34 & Id. \\
\hline 35 & Brent D. Yacobucci \& Robert Bamberger, Automobile and Light Truck Fuel Economy: The CAFE Standards CRS-4 (2006). \\
\hline 36 & Davis, Diegel \& Boundy, supra note 3, at 1-1. \\
\hline 37 & Id. \\
\hline 38 & Id. at 1-8 tbl.1.7. \\
\hline 39 & Id. at $1-10$ fig. 1.5 . \\
\hline 40 & $\begin{array}{l}\text { Id. at } 1-11 \text { tbl.1.8. (Note that reported estimates vary from } \$ 6 \text { to } \$ 60 \text { billion per year as the cost of defending U.S. interests in } \\
\text { the Persian Gulf. These estimates do not include the cost of the war in Iraq). }\end{array}$ \\
\hline 41 & $\begin{array}{l}\text { AEO2011 Early Release Overview: Energy Prices, U.S. Energy Info. Admin. (Dec. 16, 2010), http://www.eia.doe.gov/ } \\
\text { forecasts/aeo/early_prices.cfm. }\end{array}$ \\
\hline 42 & Energy Policy and Conservation Act, Pub. L. No. 94-163, 89 Stat. 871, 901-16 (1975). \\
\hline 43 & S. Rep. No. 94-516 (1975) (Conf. Rep.), reprinted in 1975 U.S.C.C.A.N. 1956, 1957. \\
\hline 44 & 49 U.S.C. $\S 32901(a)(6)$ (1994). \\
\hline 45 & $\begin{array}{l}\text { Average Fuel Economy Standards for Light Trucks Model Years 2008-2011, } 71 \text { Fed. Reg. 17,566, 17,571 (Apr. 6, 2006) } \\
\text { (codified at } 49 \text { CFR pts. 523, } 533 \text { \& 537). }\end{array}$ \\
\hline 46 & Public Citizen v. Nat’1 Highway Traffic \& Safety Admin., 848 F.2d 256 (D.C. Cir. 1988). \\
\hline 47 & Davis, Diegel \& Boundy, supra note 3, at 4-22 tbl.4.21. \\
\hline 48 & See 49 C.F.R. $\S 533.5(a),(g) \&(h)(2009)$. \\
\hline 49 & $\begin{array}{l}\text { See Average Fuel Economy Standards for Light Trucks Model Years 2008-2011, } 71 \text { Fed. Reg. 17,566, } 17,571 \text { (Apr. 6, 2006) } \\
\text { (codified at } 49 \text { C.F.R. pts. 523, 533, and 537). }\end{array}$ \\
\hline 50 & Id. \\
\hline 51 & Id. See also Davis, Diegel \& Boundy, supra note 3, at 4-23 tbl.4.22. \\
\hline
\end{tabular}




\begin{tabular}{|c|c|}
\hline 52 & Ctr. for Auto Safety v. Nat'l Highway Traffic Safety Admin., 793 F.2d 1322 (D.C. Cir. 1986). \\
\hline 53 & $\begin{array}{l}\text { See Average Fuel Economy Standards for Light Trucks Model Years 2008-2011, } 71 \text { Fed. Reg. at 17,571. Congress imposed } \\
\text { the limit in the Department of Transportation and Related Agencies Appropriations Act for FY 1996, Pub. L. No. 104-50, } \$ \\
330 \text { (1995), and continued to do this in the FY 1997-2001 appropriation acts. The effect was to freeze the MY 1997 rule for } \\
\text { MY 1997. }\end{array}$ \\
\hline 54 & $\begin{array}{l}\text { The Department of Transportation and Related Agencies Appropriations Act for FY 2002, Pub. L. No. 107-87 (2001), had no } \\
\text { provision restricting NHTSA from prescribing fuel economy standards. }\end{array}$ \\
\hline 55 & $\begin{array}{l}\text { Light Truck Average Fuel Economy Standards Model Years 2005-2007, } 68 \text { Fed. Reg. 16,868, } 16,871 \text { (Apr. 7, 2003) (codified } \\
\text { at } 49 \text { C.F.R. pt. 533). See also Brent D. Yacobucci, Cong. Research Serv., CRS Report for Congress: Sport Utility Vehicles, } \\
\text { Mini-Vans, and Light Trucks: An Overview of Fuel Economy and Emissions Standards at CRS-3 (2004), available at http:// } \\
\text { ncseonline.org/nle/crsreports/03may/rs20298.pdf. }\end{array}$ \\
\hline 56 & Davis, Diegel \& Boundy, supra note 3, at 4-23 tbl.4.22. \\
\hline 57 & 49 U.S.C. $\S 32901(a)(3)$ (2007). \\
\hline 58 & Davis, Diegel \& Boundy, supra note 3, at 4-38 tbl.4.32. \\
\hline 59 & 40 C.F.R. $\S \S 86.101$ to $86.116-12,86.1801-01$ to $86.1867-12$ (1996). \\
\hline 60 & 40 C.F.R. $\S \S 600.101-08$ to $600.115-08,600.201-08$ to $600.211-08$ (2010). \\
\hline 61 & Davis, Diegel \& Boundy, supra note 3, at 4-38 tbl.4.32. \\
\hline 62 & Id . at 4-22 tbl.4.21. \\
\hline 63 & $\begin{array}{l}\text { Pamela Najor, EPA Reports Average Fuel Economy of Model Year } 2005 \text { Vehicles Rose Slightly, } 36 \text { Env’t Rep. (BNA) } 1556 \\
\text { (July 29, 2005). }\end{array}$ \\
\hline 64 & Davis, Diegel \& Boundy, supra note 3, at 3-5 tbl.3.3 (calculated from FHWA data). \\
\hline 65 & Id. at 4-7, tbl.4.7, 4-9 tbl.4.9 (calculated from data). \\
\hline 66 & Id. \\
\hline 67 & $\begin{array}{l}49 \text { U.S.C. } \S 32912 \text { (2007). Enforcement provisions are found at } 49 \text { U.S.C. } \S \S 32913-32916 \text { (2010). Regulations for } \\
\text { calculating penalties are found at } 40 \text { C.F.R. } \S 600.510-86(\mathrm{c})(\mathbf{2 0 1 1}) \text {. }\end{array}$ \\
\hline 68 & $\begin{array}{l}\text { See generally } 40 \text { C.F.R. } \S 600.510-08 \text { (2010). The determination of what is a domestic vehicle is based on procedures } \\
\text { established by the Secretary of the Department of Transportation pursuant to } 40 \text { C.F.R. } \S 600.512-01 \text { (2010). }\end{array}$ \\
\hline 69 & $\begin{array}{l}\text { See generally Nat'l Research Council, Effectiveness and Impact of Corporate Average Fuel Economy (CAFÉ) Standards } 89 \\
\text { (2002). }\end{array}$ \\
\hline 70 & Davis, Diegel \& Boundy, supra note 3, at 4-24 tbl.4.23. \\
\hline
\end{tabular}




\begin{tabular}{|c|c|}
\hline 71 & $\begin{array}{l}\text { Summary of CAFÉ Fines Collected, Nat'l Highway Traffic Safety Admin. (Nov. 29, 2010), http:// www.nhtsa.gov/staticfiles/ } \\
\text { rulemaking/pdf/cafe/Fines_Collected_112010.pdf. }\end{array}$ \\
\hline 72 & Energy Tax Act of 1978, Pub. L. No. 95-618, 92 Stat. 3180 (codified at 26 U.S.C. $§ 4064$ (2005)). \\
\hline 73 & Pub. L. No. 101-508, 104 Stat. 1388 (1990). \\
\hline 74 & Davis, Diegel \& Boundy, supra note 3, at 4-25 tbl.4.24. \\
\hline 75 & 40 C.F.R. $\S \S 600.513-08,600.513-81$ (2010). \\
\hline 76 & Davis, Diegel \& Boundy, supra note 3, at 4-26 tbl.4.25. \\
\hline 77 & $\begin{array}{l}\text { Average Fuel Economy Standards for Light Trucks Model Years 2008-2011, } 71 \text { Fed. Reg. 17,566, 17,624 (Apr. 6, 2006) } \\
\text { (codified at } 49 \text { C.F.R. pts. 523, } 533 \text { and 537). }\end{array}$ \\
\hline 78 & Id. \\
\hline 79 & $\begin{array}{l}\text { See Average Fuel Economy Standards for Light Trucks; Model Years 2008-2011, } 70 \text { Fed. Reg. 51,414, 51,424 (Aug. } 30 \text {, } \\
2005 \text { ) (codified at } 49 \text { pts. C.F.R. 523, 533, 537). The unreformed fuel economy limits increase in stringency from the MY } \\
2007 \text { standard of } 22.2 \text { miles per gallon (mpg) to } 22.5 \mathrm{mpg} \text { in MY 2008, } 23.1 \mathrm{mpg} \text { in MY 2009, and } 23.5 \mathrm{mpg} \text { in MY } 2010 . \text { Id. } \\
\text { at } 51,414 \text {. }\end{array}$ \\
\hline 80 & Average Fuel Economy Standards for Light Trucks Model Years 2008-2011, 71 Fed. Reg. at 17,580. \\
\hline 81 & Davis, Diegel \& Boundy, supra note 3, at 4-19 tbl.4.18. \\
\hline 82 & Average Fuel Economy Standards for Light Trucks; Model Years 2008-2011,71 Fed. Reg. at 17,566. \\
\hline 83 & Id. \\
\hline 84 & $\begin{array}{l}\text { Id. at 17,570. A definition of MDPV is found in EPA's Tier } 2 \text { regulations at Tier } 2 \text { Light-Duty Vehicle and Light-Duty Truck } \\
\text { Emission Standards and Gasoline Sulfur Control Requirements, } 65 \text { Fed. Reg. } 6698 \text { (Feb. 10, 2000) (codified at } 40 \text { C.F.R. pts. } \\
\text { 80, 85, \& 86). }\end{array}$ \\
\hline 85 & Average Fuel Economy Standards for Light Trucks Model Years 2008-2011, 71 Fed. Reg. at 17,654. \\
\hline 86 & $\begin{array}{l}\text { Ctr. for Biological Diversity v. Nat’l Highway Traffic Safety Admin., } 508 \text { F.3d 508, } 513 \text { (9th Cir. 2007). The eleven states } \\
\text { involved in the challenge were California, Connecticut, Maine, Massachusetts, New Jersey, New Mexico, New York, Oregon, } \\
\text { Rhode Island, Vermont, and Minnesota. Id. }\end{array}$ \\
\hline 87 & 42 U.S.C. $\S \S 4321-4347$ (1975). \\
\hline 88 & Ctr. for Biological Diversity v. Nat’l Highway Traffic Safety Admin., 508 F.3d 508, 513 (9th Cir. 2007). \\
\hline 89 & Id. \\
\hline
\end{tabular}




\begin{tabular}{|c|c|}
\hline 90 & Id. \\
\hline 91 & Id. at $513-14$. \\
\hline 92 & Id. at 514 . \\
\hline 93 & Id. at 531 . \\
\hline 94 & See id. at 517 n.11. \\
\hline 95 & Id. at 532 . \\
\hline 96 & Id. at 514 . \\
\hline 97 & $\begin{array}{l}\text { See Ctr. for Biological Diversity v. Nat'1 Highway Traffic Safety Admin., 538 F.3d 1172, } 1182 \text { (9th Cir. 2008). NHTSA's } \\
\text { draft Environmental Impact Statement was released June 26, 2008, and was criticized by EPA as underestimating the benefits } \\
\text { of reducing GHGs. On August 18, 2008, the Ninth Circuit amended its order so that NHTSA need only revise its } \\
\text { environmental analysis, but must consider the benefits of reducing } \mathrm{CO}_{2} \text { emissions. Id. }\end{array}$ \\
\hline 98 & $\begin{array}{l}549 \text { U.S. 497, } 529 \text { (2007). The history of Massachusetts v. EPA is covered in detail in Arnold W. Reitze, Jr., Controlling } \\
\text { Greenhouse Emissions From Mobile Sources--Massachusetts v. EPA, } 37 \text { Envtl. L. Rep. 10,535 (July 2007). }\end{array}$ \\
\hline 99 & Energy Independence and Security Act, Pub. L. No. 110-140 (2007). \\
\hline 100 & See id. \\
\hline 101 & $\begin{array}{l}\text { Steven D. Cook, Growth in Vehicle Travel May Wipe Out Emissions Reductions from New CAFÉ Bill, } 39 \text { Env’t Rep. (BNA) } \\
158 \text { (Jan. 25, 2008). }\end{array}$ \\
\hline 102 & 49 U.S.C. $\S 32902(b)(2)(A)$. \\
\hline 103 & $\begin{array}{l}\text { Energy Independence and Security Act, Pub. L. No. 110-140, } \S 102(b)(2)(B), 121 \text { Stat. 1498-1501 (2007). 49 U.S.C. } \S \\
32902 \text { (f) states: "When deciding maximum feasible average fuel economy under this section, [the NHTSA] shall consider } \\
\text { technological feasibility, economic practicability, the effect of other motor vehicle standards of the Government on fuel } \\
\text { economy, and the need of the United States to conserve energy." }\end{array}$ \\
\hline 104 & Energy Independence and Security Act $§ 102$. \\
\hline 105 & 49 U.S.C. $\S 32902(\mathrm{k})$. \\
\hline 106 & $\begin{array}{l}\text { CAFE Overview - Frequently Asked Questions, Nat'l Highway Traffic Safety Admin., http://www.nhtsa.gov/cars/rules/cafe/ } \\
\text { overview.htm (last visited Feb. 16, 2011). }\end{array}$ \\
\hline
\end{tabular}




\begin{tabular}{|c|c|}
\hline 107 & $\begin{array}{l}\text { Energy Independence and Security Act, Pub. L. No. 110-140 (2007). Fuel economy labeling requirements were promulgated } \\
\text { at Fuel Economy Labeling of Motor Vehicles: Revisions to Improve Calculation of Fuel Economy Estimates, } 71 \text { Fed. Reg. } \\
77,872 \text { (Dec. 27, 2006) (codified at } 40 \text { C.F.R. pts. } 86 \text { and 600). On August 30, 2010, EPA and NHTSA announced a proposed } \\
\text { rule to modify the fuel economy ratings. See Fuel Economy: Regulations and Standards, U.S.E.P.A., http://www.epa.gov/ } \\
\text { fueleconomy/regulations.htm (last visited Feb. 7, 2011). The proposed rule includes two options. Revisions and Additions to } \\
\text { Motor Vehicle Fuel Economy Label, } 75 \text { Fed. Reg. 58,077 (proposed Sept. 23, 2010) (to be codified at } 40 \text { C.F.R. pts. 136, } \\
\text { 260, 423, 430, \& 435). The first option is to give cars and light-duty trucks letter grades from A to D based on their fuel } \\
\text { economy and GHG emissions. Id. The second option is to continue the existing approach, but to display figures for fuel } \\
\text { economy and the cost of fuel needed to operate the vehicle. Id. On September 23, 2010, EPA also promulgated a third label } \\
\text { design for comment: Revisions and Additions to Motor Vehicle Fuel Economy Label, } 75 \text { Fed. Reg. 58,127 (proposed Sept. } \\
\text { 23, 2010) (to be codified at } 49 \text { C.F.R. pt. 575). }\end{array}$ \\
\hline 108 & Energy Independence and Security Act, Pub. L. No. 110-140, § 108 (2007). \\
\hline 109 & $\begin{array}{l}\text { Id. The } 2007 \text { legislation includes a trading program in } \S 104 \text { that allows manufacturers who exceed the standards for certain } \\
\text { models to obtain credits that can be applied to other vehicles in the manufacturer's fleet that fail to meet the standard. Id. } \S \\
108 \text {. The act also includes new labeling requirements in } \S 105 \text { aimed at requiring more accurate fuel efficiency information } \\
\text { as well as information on GHG emissions. Id. } \S 105 \text {. This will require new regulations to be promulgated that will be } \\
\text { applicable in about four years. }\end{array}$ \\
\hline 110 & $\begin{array}{l}\text { Fred Sissine, Cong. Research Serv., CRS Report for Congress: Energy Independence and Security Act of 2007: A Summary } \\
\text { of Major Provisions } 2 \text { (Dec. 21, 2007). }\end{array}$ \\
\hline 111 & Id. \\
\hline 112 & $\begin{array}{l}\text { Average Fuel Economy Standards, Passenger Cars and Light Trucks; Model Years 2011-2015, } 73 \text { Fed. Reg. } 24,352 \text { (proposed } \\
\text { May 2, 2008) (to be codified at } 49 \text { C.F.R. pts. 523, 531, 533-537). }\end{array}$ \\
\hline 113 & $\begin{array}{l}\text { Id. at 24,353. See also Steven D. Cook, Transportation Department Proposes Increase In Fuel Economy Standards for } \\
\text { 2011-2015, } 39 \text { Env't Rep. (BNA) } 794 \text { (Apr. 25, 2008). }\end{array}$ \\
\hline 114 & $\begin{array}{l}\text { See Average Fuel Economy Standards Passenger Cars and Light Trucks Model Year 2011, } 74 \text { Fed. Reg. 14,196, 14,199 (Mar. } \\
\text { 30, 2009) (to be codified at } 49 \text { C.F.R. pts. 523, 531, 533-537). }\end{array}$ \\
\hline 115 & Id. at $14,199$. \\
\hline 116 & Id. at $14,196$. \\
\hline 117 & Id. \\
\hline 118 & Id. at 14,201 \\
\hline 119 & Id. at $14,196$. \\
\hline 120 & Id. at 14,204 \\
\hline 121 & Id. at 14,205 . \\
\hline 122 & Id. \\
\hline
\end{tabular}




\begin{tabular}{|c|c|}
\hline 123 & $\begin{array}{l}\text { Because all the carbon in a fuel becomes } \mathrm{CO}_{2} \text {, limiting the fuel that can be combusted controls } \mathrm{CO}_{2} \text { emissions, and vice } \\
\text { versa. See supra notes } 12-14 \text {, and accompanying text. }\end{array}$ \\
\hline 124 & $\begin{array}{l}\text { Proposed Rulemaking To Establish Light-Duty Vehicle Greenhouse Gas Emission Standards and Corporate Average Fuel } \\
\text { Economy Standards, } 74 \text { Fed. Reg. } 49,454 \text { (Sept. 28, 2009) (to be codified at } 40 \text { C.F.R. pts. } 86 \text { \& 600). }\end{array}$ \\
\hline 125 & Massachusetts v. EPA, 549 U.S. 497, 529 (2007). \\
\hline 126 & 42 U.S.C. $\S 7521(a)(1)$. \\
\hline 127 & 42 U.S.C. $\S 7521(a)(2)$. \\
\hline 128 & $\begin{array}{l}\text { Proposed Endangerment and Cause or Contribute Findings for Greenhouse Gases Under Section 202(a) of the Clean Air Act, } \\
74 \text { Fed. Reg. 18,886 (proposed Apr. 24, 2009) (to be codified in } 40 \text { C.F.R. ch. 1). }\end{array}$ \\
\hline 129 & $\begin{array}{l}\text { Endangerment and Cause or Contribute Findings for Greenhouse Gases Under Section 202(a) of the Clean Air Act, } 74 \text { Fed. } \\
\text { Reg. 66,496 (Dec. 15, 2009) (to be codified in } 40 \text { C.F.R. ch. 1). }\end{array}$ \\
\hline 130 & $\begin{array}{l}\text { Steven D. Cook, Sixteen Lawsuits Filed Challenging EPA Rule That Greenhouse Gas Emissions Pose Danger, } 41 \text { Env't. Rep. } \\
\text { (BNA) } 363 \text { (Feb. 19, 2010). Petitioners include three states, twelve Republican members of Congress and many industry } \\
\text { trade organizations. Id. In May 2010, the National Electrical Manufacturers Association (NEMA) was added to the industry } \\
\text { groups challenging the endangerment finding. See Electrical Manufacturers Challenge Greenhouse Gas Endangerment } \\
\text { Finding, } 21 \text { Clean Air Rep. (Inside EPA) } 11 \text { (May 27, 2010). In addition, ten petitions were filed with EPA to reconsider its } \\
\text { endangerment finding. }\end{array}$ \\
\hline 131 & $\begin{array}{l}\text { See EPA Rejects } 10 \text { Petitions to Reconsider Climate Risk Finding, } 21 \text { Clean Air Rep. (Inside EPA) } 16 \text { (Aug. 5, 2010). They } \\
\text { were rejected on July 29, 2010. Id. }\end{array}$ \\
\hline 132 & $\begin{array}{l}\text { Id.; U.S. Chamber Sues EPA over Rejection of GHG Endangerment Petition, } 21 \text { Clean Air Rep. (Inside EPA) } 17 \text { (Aug. } 19 \text {, } \\
\text { 2010). }\end{array}$ \\
\hline 133 & Coal for Responsible Regulation, Inc. v. EPA, No. 09-1322, No. 10-1073, No. 10-1092 (D.C. Cir. Dec. 10, 2010). \\
\hline 134 & $\begin{array}{l}\text { Murkowski Seen Eyeing Jobs Debate for Push to Block EPA Climate Rules, } 27 \text { Envtl. Pol'y Alert (Inside EPA) } 2 \text { (Jan. } 27, \\
\text { 2010). See also NHTSA Joins EPA in Opposing Murkowski Push to Block Vehicle GHG Rules, } 21 \text { Clean Air Rep. (Inside } \\
\text { EPA) } 5 \text { (Mar. 4, 2010). }\end{array}$ \\
\hline 135 & $\begin{array}{l}\text { Doug Obey, Senate Climate Agenda Remains Murky as Democrats Acknowledge Split, } 27 \text { Envtl. Pol'y Alert (Inside EPA) } 12 \\
\text { (June 16, 2010). }\end{array}$ \\
\hline 136 & $\begin{array}{l}\text { See Steven D. Cook, Skelton, Peterson, Emerson Introduce Bill to Eliminate EPA Greenhouse Gas Authority, } 41 \text { Env’t. Rep. } \\
\text { (BNA) } 261 \text { (Feb. 5, 2010). }\end{array}$ \\
\hline 137 & $\begin{array}{l}\text { Light-Duty Vehicle Greenhouse Gas Emission Standards and Corporate Average Fuel Economy Standards, } 75 \text { Fed. Reg. } \\
\text { 25,324 (May 7, 2010). }\end{array}$ \\
\hline 138 & Id. at 25,328 \\
\hline 139 & Id. \\
\hline
\end{tabular}




\begin{tabular}{|c|c|}
\hline 140 & See id. at 25,408 . \\
\hline 141 & $\begin{array}{l}\text { Steven D. Cook, Automobile Industry Drops Lawsuits Against States Adopting California Standards, 41 Env’t. Rep. (BNA) } \\
778 \text { (Apr. 9, 2010) (The cases dismissed include Central Valley Chrysler-Jeep, v. Goldstene, No. 08-17378 (9th Cir. Apr. 7, } \\
2010 \text { ), Association of International Automobile Manufacturers v. Sullivan, No. 09-1023 (1st Cir. Apr. 7, 2010), and Green } \\
\text { Mountain Chrysler-Plymouth-Dodge v. Crombie, No. 07-4342-cv (2d Cir. Apr. 7, 2010)). See also Automakers Drop } \\
\text { Challenge to GHG Rules, Reserve Right for Post-2016 Suits, 21 Clean Air Rep. (Inside EPA) 8 (Apr. 15, 2010); Jackson } \\
\text { Vows to Begin Negotiations over Post-2016 Vehicle Rules, 21 Clean Air Rep. (Inside EPA) } 10 \text { (May 13, 2010). }\end{array}$ \\
\hline 142 & $\begin{array}{l}\text { Coal. for Responsible Regulation, Inc. v. EPA, No. 10-1092 (D.C. Cir. 2010). States and the automobile industry are seeking } \\
\text { to intervene on behalf of EPA. Carolyn Whetzel, States, Automakers Support EPA in Industry Challenge to Vehicle Rules, } 41 \\
\text { Env't. Rep. (BNA) } 1295 \text { (June 11, 2010). }\end{array}$ \\
\hline 143 & $\begin{array}{l}\text { Light-Duty Vehicle Greenhouse Gas Emission Standards and Corporate Average Fuel Economy Standards, } 75 \text { Fed. Reg. at } \\
25,330 .\end{array}$ \\
\hline 144 & Id. \\
\hline 145 & Id. \\
\hline 146 & $\begin{array}{l}\text { Id. The final CAFÉ standards for passenger cars from the MY } 2011 \text { base are } 30.4 \text { in FY2011; } 33.4 \text { in FY2012; } 34.2 \text { in } \\
\text { FY2013; } 34.9 \text { in FY2014; } 36.2 \text { in FY2015; and } 37.8 \text { in FY2016. Id. For light trucks the standards are } 24.4,25.4,26.0,26.6 \text {, } \\
\text { 27.5, and } 28.8 \text { mpg. Id. The fuel economy of the combined fleet is estimated at } 27.6 \text { mph in FY2011 and increases to } 34.1 \\
\text { mpg in FY2016. Id. }\end{array}$ \\
\hline 147 & $\begin{array}{l}\text { Rick Mitchell, New U.S. Vehicle Rules Likely to Cut Demand for Gas Despite Light Truck Bias, IEA Says, } 41 \text { Env’t. Rep. } \\
\text { (BNA) } 827 \text { (Apr. 16, 2010). }\end{array}$ \\
\hline 148 & See id. \\
\hline 149 & $\begin{array}{l}\text { Memorandum on Improving Energy Security, American Competitiveness and Job Creation, and Environment Protection } \\
\text { Through a Transformation of Our Nation's Fleet of Cars and Trucks, } 75 \text { Fed. Reg. 29,399, 29,400 (May 21, 2010) } \\
\text { [hereinafter "President Obama's Memo"]. }\end{array}$ \\
\hline 150 & Id. \\
\hline 151 & $\begin{array}{l}\text { Id.; } 2017 \text { and Later Model Year Light Duty Vehicle GHG Emissions and CAFÉ Standards; Notice of Intent, } 75 \text { Fed. Reg. } \\
62,739,62,742 \text { (Oct. 13, 2010) (to be codified at } 40 \text { C.F.R. pts. 85, 86, \& } 600 \text { and } 49 \text { C.F.R. pts. } 531 \text { \& 533) (discussing the } \\
\text { assessment created by the Department of Transportation). }\end{array}$ \\
\hline 152 & $\begin{array}{l}2017 \text { and Later Model Year Light Duty Vehicle GHG Emissions and CAFÉ Standards; Notice of Intent, } 75 \text { Fed. Reg. at } \\
62,739 .\end{array}$ \\
\hline 153 & Id. at 62,744 \\
\hline 154 & Id. \\
\hline 155 & $\begin{array}{l}\text { Id. at } 62,750 \text {. See also, e.g., Steven D. Cook, Environmental Groups Urge Administration to Seek } 60 \text { Miles per Gallon Cars } \\
\text { by 2025, } 41 \text { Env't Rep. (BNA) } 2067 \text { (Sept. 17, 2010); Auto Industry Criticizes EPA Cost Estimates to Oppose Strict GHG } \\
\text { Rules, } 27 \text { Envtl. Pol'y Alert (Inside EPA) } 21 \text { (Oct. 20, 2010). }\end{array}$ \\
\hline
\end{tabular}




\begin{tabular}{|c|c|}
\hline 156 & $\begin{array}{l}2017 \text { and Later Model Year Light-Duty Vehicle GHG Emissions and CAFÉ Standards: Supplemental Notice of Intent, } 75 \\
\text { Fed. Reg. } 76,337 \text { (Dec. 8, 2010) (to be codified at } 40 \text { C.F.R. pts. 85, } 86 \text { \& 600). }\end{array}$ \\
\hline 157 & See President Obama's Memo, supra note 149. \\
\hline 158 & Id. at 29,399 . \\
\hline 159 & $\begin{array}{l}\text { Id. at 29,400; U.S. Envtl. Protection Agency, Regulatory Announcement: EPA and NHTSA to Propose Greenhouse Gas and } \\
\text { Fuel Efficiency Standards for Heavy-Duty Trucks; Begin Process for Further Light-Duty Standards } 3 \text { (May, 2010), available } \\
\text { at http:// www.epa.gov/oms/climate/regulations/420f10038.pdf [hereinafter EPA-420-F-10-038]. }\end{array}$ \\
\hline 160 & $\begin{array}{l}\text { U.S. Envtl. Protection Agency, Regulatory Announcement: EPA \& NHTSA Propose First-Ever Program to Reduce } \\
\text { Greenhouse Gas Emissions and Improve Fuel Efficiency of Medium- and Heavy-Duty Vehicles } 1 \text { (October, 2010), available } \\
\text { at http://www.epa.gov/otaq/climate/regulations/420f10901.pdf. }\end{array}$ \\
\hline 161 & $\begin{array}{l}\text { Greenhouse Gas Emissions Standards and Fuel Efficiency Standards for Medium- and Heavy-Duty Engines and Vehicles, } 75 \\
\text { Fed. Reg. 74,152 (proposed Nov. 30, 2010) (to be codified at } 49 \text { C.F.R. pts. 523, 534, \& 535). }\end{array}$ \\
\hline 162 & Id. at 74,156 . \\
\hline 163 & $\begin{array}{l}\text { Id. at 74,157-58. See also Control of Air Pollution from New Motor Vehicles: Heavy-Duty Engine and Vehicle Standards and } \\
\text { Highway Diesel Fuel Sulfur Control Requirements, } 66 \text { Fed. Reg. 5,002 (Jan. 18, 2001) (codified at } 40 \text { CFR Parts } 69,80 \text { \& } \\
\text { 86) (EPA's most recent rule covering conventional pollutants from heavy-duty vehicles). }\end{array}$ \\
\hline 164 & EPA-420-F-10-038, supra note 159 , at 2. \\
\hline 165 & $\begin{array}{l}\text { Greenhouse Gas Emissions Standards and Fuel Efficiency Standards for Medium- and Heavy-Duty Engines and Vehicles, } 75 \\
\text { Fed. Reg. at 74,156. }\end{array}$ \\
\hline 166 & $\begin{array}{l}\text { Id. ("Heavy-duty vehicles are primarily powered by diesel engines, although about } 37 \text { percent of these vehicles are powered } \\
\text { by gasoline engines."). }\end{array}$ \\
\hline 167 & Id. at 74,157 . \\
\hline 168 & Id. at 74,152 . \\
\hline 169 & Id. \\
\hline 170 & Id. at 74,173. See also 49 U.S.C. $\S 32901(a)(7)$ (2007). \\
\hline 171 & $\begin{array}{l}\text { Greenhouse Gas Emissions Standards and Fuel Efficiency Standards for Medium- and Heavy-Duty Engines and Vehicles, } 75 \\
\text { Fed. Reg. at 74,159-60. }\end{array}$ \\
\hline 172 & Id. at 74,158 (emphasis removed). \\
\hline 173 & Id. at 74,158 n. 17 . \\
\hline 174 & See 49 U.S.C. $\S 32902$ (2007). \\
\hline
\end{tabular}




\begin{tabular}{|c|c|}
\hline 175 & $\begin{array}{l}\text { Greenhouse Gas Emissions Standards and Fuel Efficiency Standards for Medium- and Heavy-Duty Engines and Vehicles, } 75 \\
\text { Fed. Reg. at 74,159. }\end{array}$ \\
\hline 176 & See id. at 74,160 \& tbl.I-1. \\
\hline 177 & Id. at 74,160 . \\
\hline 178 & Id. \\
\hline 179 & Id. \\
\hline 180 & Id. at 74,161 . \\
\hline 181 & $\begin{array}{l}\text { Id. at 74,152. See also EPA Urged to End Trailer Exemption to Boost GHG Cuts in Trucking Rule, } 21 \text { Clean Air Rep. (Inside } \\
\text { EPA) } 22 \text { (Oct. 28, 2010). }\end{array}$ \\
\hline 182 & $\begin{array}{l}\text { Greenhouse Gas Emissions Standards and Fuel Efficiency Standards for Medium- and Heavy-Duty Engines and Vehicles, } 75 \\
\text { Fed. Reg. at } 74,160 .\end{array}$ \\
\hline 183 & Id. \\
\hline 184 & Id. at 74,165 . \\
\hline 185 & Id. \\
\hline 186 & Id. \\
\hline 187 & Id. at $74,165,74,174$. \\
\hline 188 & Id. at 74,164 . \\
\hline 189 & Id. \\
\hline 190 & Id. at $74,189$. \\
\hline 191 & Id. at $74,160-61$ \\
\hline 192 & Id. at 74,164 . \\
\hline 193 & Id. \\
\hline 194 & Id. \\
\hline 195 & Id. at 74,161 . \\
\hline
\end{tabular}




\begin{tabular}{|c|c|}
\hline 196 & Id. \\
\hline 197 & Id. at 74,162 tbl.I-2. \\
\hline 198 & Id. at $74,161-74,162$. \\
\hline 199 & Id. at 74,163 . \\
\hline 200 & $\begin{array}{l}\text { Id. at 74,117, 74,163 ("EPA's existing criteria pollutant emissions regulations for heavy-duty highway engines establish four } \\
\text { regulatory categories that represent the engine's intended and [sic] primary truck application. The Light Heavy-Duty (LHD) } \\
\text { diesel engines are intended for application in Class } 2 \mathrm{~b} \text { through Class } 5 \text { trucks }(8,501 \text { through } 19,500 \text { pounds GVWR). The } \\
\text { Medium Heavy-Duty (MHD) diesel engines are intended for Class } 6 \text { and Class } 7 \text { trucks }(19,501 \text { through } 33,000 \text { pounds } \\
\text { GVWR). The Heavy Heavy-Duty (HDD) diesel engines are primarily used in Class } 8 \text { trucks }(33,001 \text { pounds and greater } \\
\text { GVWR). Lastly, spark ignition engines (primarily gasoline-powered engines) installed in incomplete vehicles less than } \\
14,000 \text { pounds GVWR and spark ignition engines that are installed in all vehicles (complete or incomplete) greater than } \\
14,000 \text { pounds GVWR are grouped into a single engine regulatory subcategory. The engines in these four regulatory } \\
\text { subcategories range in size between approximately five liters and sixteen liters.... For the purposes of the GHG engine } \\
\text { emissions and engine fuel consumption standards that EPA and NHTSA are proposing, the agencies intend to maintain these } \\
\text { same four regulatory subcategories."). }\end{array}$ \\
\hline 201 & Id. at 74,159 . \\
\hline 202 & Id. at 74,161 . \\
\hline 203 & Id. at 74,163 . \\
\hline 204 & Id. at 74,178 . \\
\hline 205 & Id. at 74,167 tbl.I-4. \\
\hline 206 & Id. at 74,164 . \\
\hline 207 & Id. at 74,173 . \\
\hline 208 & Id. at 74,312 tbls. VIII-3 to VIII-6. \\
\hline 209 & Id. at 74,315 tbl.VIII-9. \\
\hline 210 & Id. at 74,325 tbl.VIII- 16. \\
\hline 211 & $\begin{array}{l}\text { Air Quality Act of } 1967, \text { Pub. L. No. } 90-148, \S 208,81 \text { Stat. 485, } 501 \text { (1967). See generally Harold W. Kennedy \& Martin E. } \\
\text { Weekes, Control of Automobile Emissions - California Experience and the Federal Legislation, } 33 \text { Law \& Contemp. Probs. } \\
297 \text { (1968). }\end{array}$ \\
\hline 212 & CAA $\S 209(b), 42$ U.S.C. $\S 7543(b)$ (2006). \\
\hline 213 & Id. \\
\hline
\end{tabular}




\begin{tabular}{|c|c|}
\hline 214 & See id. $\S 7507(2)(2006)$. \\
\hline 215 & See generally Reitze, supra note 10 , at 356 . \\
\hline 216 & $\begin{array}{l}\text { California Envtl. Prot. Agency Air Res. Bd., Low-Emission Vehicle Program, available at http://www.arb.ca.gov/msprog/ } \\
\text { levprog/levprog.htm (last visited Feb. 8, 2011) [hereinafter CARB, LEV Program]. }\end{array}$ \\
\hline 217 & $\begin{array}{l}\text { California Envtl. Prot. Agency Air Res. Bd., LEV II- Amendments to California's Low-Emission Vehicle Regulations, } \\
\text { available at http:// www.arb.ca.gov/msprog/levprog/levii/factsht.pdf. }\end{array}$ \\
\hline 218 & Id. \\
\hline 219 & Id. \\
\hline 220 & Id. \\
\hline 221 & Id. \\
\hline 222 & Cal. Assemb. B. 1493, 2001-2002 Sess. (Cal. 2001). \\
\hline 223 & Id. \\
\hline 224 & CARB, LEV Program, supra note 216. \\
\hline 225 & $\begin{array}{l}\text { California Envtl. Prot. Agency Air Res. Bd., Frequently Asked Questions: Climate Change Emissions Standards for Vehicles, } \\
\text { available at http://www.arb.ca.gov/cc/factsheets/ccfaq.pdf. }\end{array}$ \\
\hline 226 & $\begin{array}{l}\text { Clean Car Standards - Pavley, Assembly Bill 1493, California Envtl. Prot. Agency Air Res. Bd., http://www.arb.ca.gov/cc/ } \\
\text { ccms/ccms.htm (last visited Feb. 11, 2011). }\end{array}$ \\
\hline 227 & Cent. Valley Chrysler v. Witherspoon, 456 F. Supp. 2d 1160 (E.D. Cal. 2006). \\
\hline 228 & $\begin{array}{l}\text { Carolyn Whetzel, Auto Industry Challenge to California Rules Stayed Pending Decision on EPA Authority, } 38 \text { Env't Rep. } \\
\text { (BNA) } 134 \text { (Jan. 19, 2007). }\end{array}$ \\
\hline 229 & $\begin{array}{l}\text { California Envtl. Prot. Agency Air Res. Bd., Fact Sheet, The Zero Emission Vehicle Program - 2008, available at http:// } \\
\text { www.arb.ca.gov/msprog/zevprog/factsheets/2008zevfacts.pdf. }\end{array}$ \\
\hline 230 & $\begin{array}{l}\text { Carolyn Whetzel, Air Board Trims Zero-Emission Vehicle Goal, Establishes First-Time Target for Plug-Ins, } 39 \text { Env’t Rep. } \\
\text { (BNA) } 675 \text { (April 4, 2008). }\end{array}$ \\
\hline 231 & Massachusetts v. EPA, 549 U.S. 497 (2007). \\
\hline 232 & $\begin{array}{l}\text { See James E. McCarthy \& Robert Meltz, Cong. Research Serv., CRS Report for Congress: California's Waiver Request to } \\
\text { Control Greenhouse Gases Under the Clean Air Act CRS-4 n.9 (Oct. 1, 2007), available at http:// ncseonline.org/NLE/ } \\
\text { CRSreports/07Oct/RL34099.pdf. }\end{array}$ \\
\hline
\end{tabular}




\begin{tabular}{|c|c|}
\hline 233 & $\begin{array}{l}\text { California Envtl. Prot. Agency Air Res. Bd., Clean Car Standards - Pavley, Assembly Bill 1493, available at http:// } \\
\text { www.arb.ca.gov/cc/ccms/ccms.htm (last visited Jan. 25, 2011). }\end{array}$ \\
\hline 234 & $\begin{array}{l}\text { McCarthy \& Meltz, supra note 232, at CRS-7. This report analyzes the legal requirements for granting or denying a waiver. } \\
\text { Id. Four tests are identified: (1) whether the state has determined that its standards will be, in the aggregate, at least as } \\
\text { protective of public health and welfare as the applicable federal standard; (2) whether this determination was arbitrary and } \\
\text { capricious; (3) whether the state needs such standards to meet compelling and extraordinary conditions; (4) and whether the } \\
\text { standards and accompanying enforcement procedures are consistent with section 202(a) of the Clean Air Act. Id. at CRS-14. } \\
\text { The tenor of the report supports California's position that EPA acted illegally. See id. }\end{array}$ \\
\hline 235 & See Cook, supra note 130 and accompanying text. \\
\hline 236 & State of California Request for Waiver Under 42 U.S.C. 7543(b), the Clean Air Act, 74 Fed. Reg. 4905, 4907 (Jan. 28, 2009$).$ \\
\hline 237 & California Envtl. Prot. Agency Air Res. Bd., Clean Car Standards, supra note 233. \\
\hline 238 & McCarthy \& Meltz, supra note 232 , at CRS-2. \\
\hline 239 & $\begin{array}{l}\text { EPA Waiver Preserves California's Right For } 2017 \text { Vehicle GHG Standards, } 26 \text { Envtl. Pol'y Alert (Inside EPA) } 13 \text { (July } 1 \text {, } \\
\text { 2009). }\end{array}$ \\
\hline 240 & $\begin{array}{l}\text { Cal. Code Regs. tit. 13, } \S 1961.1(\mathrm{a})(1)(\mathrm{A})(2010) \text {; CARB's GHG regulations address } \mathrm{CO}_{2} \text {, methane, nitrous oxide and } \\
\text { hydrofluorocarbons and the control level is based on each gas's global warming potential. Id. } \S 1961(\mathrm{~d}) \text {. }\end{array}$ \\
\hline 241 & See id. $\S 1961.1(a)(1)(A)$. \\
\hline 242 & See id. $\S 1961.1(a)(1)(A),(D)$. \\
\hline 243 & New Briefs, 15 Clean Air Rep. (Inside EPA) 17 (August. 12, 2004). \\
\hline 244 & See supra notes $120-130$ and the accompanying text. \\
\hline 245 & $\begin{array}{l}\text { Steven D. Cook \& Carolyn Whetzel, EPA Grants California Waiver to Implement Greenhouse Gas Emissions Limits on Cars, } \\
40 \text { Envt. Rep. (BNA) } 1551 \text { (July 3, 2009). }\end{array}$ \\
\hline 246 & $\begin{array}{l}\text { EPA Asserts GHG Role in Comments on NHTSA Fuel Economy Process, } 20 \text { Clean Air Rep. (Inside EPA) } 10 \text { (May } 14 \text {, } \\
\text { 2009); Automakers to Drop GHG Litigation in California Emissions Deal, } 26 \text { Envtl. Pol'y Alert } 10 \text { (May 20, 2009). }\end{array}$ \\
\hline 247 & 2006 Cal. Legis. Serv. Ch. 488 (West). \\
\hline 248 & $\begin{array}{l}\text { California Envtl. Prot. Agency Air Res. Bd., California Draft Resolution on California Cap-and-Trade Program Res. 10-42 at } \\
\text { 5, adopted with modifications Dec. 16, 2010, available at http:// www.arb.ca.gov/cc/capandtrade/capandtrade/ } \\
\text { draft } \% 20 \text { resolution.pdf. }\end{array}$ \\
\hline 249 & Id. \\
\hline 250 & $\begin{array}{l}\text { Carolyn Whetzel, State Issues Draft Emissions Trading Rules for } 2012 \text { with Most Allowances Given Away, } 41 \text { Envtl. Rep. } \\
\text { (BNA) } 2478 \text { (Nov. 5, 2010). }\end{array}$ \\
\hline
\end{tabular}




\begin{tabular}{|c|c|}
\hline 251 & $\begin{array}{l}\text { California Envtl. Prot. Agency Air Res. Bd., California Draft Resolution on California Cap-and-Trade Program Res. 10-42 at } \\
\text { 5, adopted with modifications, Dec. 16, 2010, available at http:// www.arb.ca.gov/cc/capandtrade/capandtrade/ } \\
\text { draft } \% 20 \text { resolution.pdf. }\end{array}$ \\
\hline 252 & Id. \\
\hline 253 & Id. \\
\hline 254 & Id. \\
\hline 255 & $\begin{array}{l}\text { See News Release: California Air Resources Board gives green light to California's emissions trading program, California } \\
\text { Envtl. Prot. Agency Air Res. Bd. (Dec, 16, 2010), http://www.arb.ca.gov/newsrel/newsrelease.php? id=170. }\end{array}$ \\
\hline 256 & $\begin{array}{l}\text { See Califorina Secretary of State, Propositions: Proposition 23, Cal. Voter Info. Guide, Nov. 2, 2010, http:// } \\
\text { www.voterguide.sos.ca.gov/propositions/23/ (last visited Feb. 8, 2011). }\end{array}$ \\
\hline 257 & Id. \\
\hline 258 & $\begin{array}{l}\text { Cal. Secretary of State: Votes For and Against: November 2, } 2010 \text { Statewide Ballot Measures, http://www.sos.ca.gov/ } \\
\text { elections/sov/2010-general/07-for-against.pdf. }\end{array}$ \\
\hline 259 & $\begin{array}{l}\text { Daniel B. Wood, Texas Oil Firms Behind California Greenhouse Gas Initiative, The Christian Science Monitor, June } 23 \text {, } \\
\text { 2010, available at http:// www.csmonitor.com/layout/set/print/content/view/print/310250. }\end{array}$ \\
\hline 260 & $\begin{array}{l}\text { See Califorina Secretary of State, Propositions: Proposition 26, Cal. Voter Info. Guide Nov. 2, 2010, http:// } \\
\text { www.voterguide.sos.ca.gov/propositions/26/ (last visited Feb. 8, 2011). }\end{array}$ \\
\hline 261 & Cal. Secretary of State, supra note 258. \\
\hline 262 & $\begin{array}{l}\text { Carolyn Whetzel, Voters Approve Ballot Measure to Require Two-Thirds Vote on State Regulatory Fees, } 41 \text { Envt. Rep. } \\
\text { (BNA) } 2477 \text { (Nov. 5, 2010). }\end{array}$ \\
\hline 263 & See supra notes $149-156$ and the accompanying text. \\
\hline 264 & $\begin{array}{l}\text { David Shepardson, EPA official sees agreement with California on future emission standards, The Detroit News (Apr. } 12 \text {, } \\
\text { 2011), http:// www.detnews.com/article/20110412/AUTO01/104120407/1361/EPA-official-sees-agreement-with-California- } \\
\text { onfuture-emissions-standards. }\end{array}$ \\
\hline 265 & See Green Vehicle Guide, U.S. Envtl. Prot. Agency, http:// www.epa.gov/greenvehicles/Index.do (last visited Feb. 8, 2011). \\
\hline 266 & Davis, Diegel \& Boundy, supra note 3, at 1-16 tbl.1.12. \\
\hline 267 & $\begin{array}{l}\text { Id. } 10.89 \text { million gallons were consumed in 1990, compared with } 13.36 \text { million gallons in } 2008 \text { and } 12.91 \text { million gallons per } \\
\text { day in } 2009 . \text { Id. }\end{array}$ \\
\hline 268 & $\begin{array}{l}\text { See American Petroleum Inst., Fuel Taxes Quarterly Report (Jan. 2011), available at http://www.api.org/statistics/fueltaxes/ } \\
\text { upload/Gasoline_Diesel_Summary.pdf. }\end{array}$ \\
\hline 269 & $\begin{array}{l}\text { U.S. Dept. of Energy, Federal Tax Credits for Hybrids, available at http://www.fueleconomy.gov/feg/tax_hybrid.shtml (last } \\
\text { visited Jan. 25, 2011). }\end{array}$ \\
\hline
\end{tabular}


270 See generally Electric Power Research Inst., Environmental Assessment of Plug-in Hybrid Electric Vehicles (2007), available at http:// www.epri-reports.org (last modified Jan. 25, 2011).

271 See generally Ne. States Ctr. for a Clean Air Future, Reducing Greenhouse Gas Emissions from Light-Duty Motor Vehicles, xiv 3-1 to 3-23 (Sept. 2004).

272 Industry Shows Early Support for GHG Truck Rules at Public Hearings, 21 Clean Air Rep. (Inside EPA) 25 (Dec. 9, 2010).

\section{UTELR 309}

